\title{
Mycobacterium tuberculosis Thymidine Monophosphate Kinase Inhibitors: Biological Evaluation and Conformational Analysis of 2 '- and 3'-Modified Thymidine Analogues
}

\author{
Philippe Van Rompaey, ${ }^{[a]}$ Koen Nauwelaerts, ${ }^{[b]}$ Veerle Vanheusden, ${ }^{[a]}$ Jef Rozenski, ${ }^{[b]}$ \\ Hélène Munier-Lehmann, ${ }^{[c]}$ Piet Herdewijn, ${ }^{[b]}$ and Serge Van Calenbergh*[a]
}

Keywords: Nucleosides / Inhibitors / Drug design

Mycobacterium tuberculosis thymidine monophosphate kinase (TMPKmt) has recently been introduced as a potential target for the structure-based design of anti-tuberculosis drugs. Based on the TMPKmt X-ray structure and previous S.A.R. studies, we synthesised the nucleoside analogues $\mathbf{3 a}-\mathbf{b}, \mathbf{6 a}-\mathbf{b}, \mathbf{7 a}-\mathbf{b}$, and $\mathbf{8 a}-\mathbf{b}$, modified in $2^{\prime}-$ and $3^{\prime}$-position of the ribofuranose ring moiety. To our surprise, these analogues showed only moderate binding affinity (i.e. $K_{\mathrm{i}}$ between 118 and $1260 \mu \mathrm{M}$ ). This prompted us to investigate the conformational features of these nucleosides. We concluded that compounds of this series, especially $\mathbf{8 a}-\mathbf{b}$, are strongly biased towards the "Northern" furanose ring conformation, whereas X-ray crystallography reveals a preference of TMPKmt for the opposite "Southern" conformers. This paper covers the synthesis, biological evaluation and conformational features (i.e. preferred ring puckering) of the 2 ' - and $3^{\prime}$-modified dT analogues.

(ㄷ)Wiley-VCH Verlag GmbH \& Co. KGaA, 69451 Weinheim, Germany, 2003)

\section{Introduction}

Each year Mycobacterium tuberculosis, the intracellular parasite that causes tuberculosis (TB), kills approximately 2 million people. ${ }^{[1]}$ The World Health Organization (WHO) declared TB a global health emergency and estimates that between 2002 and 2020 approximately 1000 million people will be newly infected and 36 million will die from TB. ${ }^{[2,3]}$ Major contributors to the resurgence of this pulmonary disease and its worsening impact are the breakdown in health services, the pandemic of AIDS and the emergence of multidrug-resistant (MDR)-TB. ${ }^{[3]}$ The immune system can "wall off" the bacilli, allowing TB to stay dormant for years and to emerge when the immune system is weakened. This explains why TB is a leading cause of death among HIV-positive persons. ${ }^{[3,4]}$ The current treatment strategy of TB is based on an intensive 6 to 8 -month regimen of multiple antibiotics such as rifampicine, isoniazid, pyrazinamide, and ethambutol or streptomycin. ${ }^{[5]}$ However, Mycobacterium tuberculosis strains resistant to some or all of these major anti-TB drugs have emerged and are associated with

[a] Laboratory for Medicinal Chemistry (FFW), Ghent University, Harelbekestraat 72, 9000 Gent, Belgium

Fax: (internat) +32-(0)9-2648146

E-mail: serge.vancalenbergh@rug.ac.be

[b] Laboratory for Medicinal Chemistry, Rega Institute for Medical Research (K.U. Leuven),

Minderbroedersstraat 10, 3000 Leuven, Belgium

[c] Laboratoire de Chimie Structurale des Macromolécules (URA CNRS 2185), Institut Pasteur,

75724 Paris Cedex 15, France high death rates of $50-80 \%$. ${ }^{[6]}$ The "MDR" prefix refers to the simultaneous resistance to at least isoniazid and rifampicin, the two most potent anti-TB drugs, caused primarily by inconsistent, partial or improper treatment regimens.

These facts impose the need to identify new targets and to develop new anti-TB drugs in order to optimise and/or shorten the current TB treatment and to combat resistance. In that light, Mycobacterium tuberculosis thymidine monophosphate kinase (TMPKmt), an essential enzyme of nucleotide metabolism that catalyses the reversible phosphorylation of thymidine monophosphate (dTMP) to thymidine diphospate (dTDP), has recently been introduced as a novel potential target for chemotherapeutic intervention. ${ }^{[7,8]} \mathrm{Al}-$ though the global fold of the TMPKmt enzyme is similar to that of other TMPK isozymes, it has a low degree of amino acid sequence identity with the E. coli (26\%), yeast $(25 \%)$ and human $(22 \%)$ isozymes, making it an attractive target for blocking mycobacterial DNA synthesis. ${ }^{[8]}$ The Xray structure of the dTMP-TMPKmt complex indicated that the main binding interactions between dTMP and the enzyme involve both its pyrimidine base (i.e. stacking interaction with Phe 70 and $O 4$ and $N 3$ participating in hydrogen bonding with Arg74 and Asn100) and its ribofuranose ring moiety (i.e. hydrogen bond between the 3'-hydroxyl of dTMP and the terminal carboxyl of Asp9). ${ }^{[8]}$ The presence of a tyrosine residue (Tyr103) close to the $2^{\prime}$-position allows the enzyme to discriminate between $2^{\prime}$-deoxynucleotides and ribonucleotides, only transforming the former. ${ }^{[8]}$ Also this X-ray analysis revealed the substrate to adopt the "Southern" conformation. ${ }^{[8]}$ 
The fact that thymidine (dT) and 3'-azido-3'-deoxythymidine (AZT) proved to be competitive inhibitors of TMPKmt with low $\mu$ M affinity, ${ }^{[9]}$ led towards the synthesis and biological evaluation of several dT nucleoside and nucleotide analogues. ${ }^{[9-11]}$ In this paper we continue our search for nucleosidic TMPKmt inhibitors by combining favourable modifications at C-3' $\left(\mathrm{N}_{3}, \mathrm{NH}_{2}\right)$ with the beneficial effects observed upon introduction of an $\alpha$-chloro or $\alpha$-fluoro substituent at C-2' ${ }^{[10,11]}$ Using NMR spectroscopy and pseudorotational analysis, we examined the solution state conformation of the sugar ring of the synthesised analogues to gain better insight into the molecular determinants of TMPKmt inhibition.

\section{Results and Discussion}

\section{Chemical Synthesis of $2^{\prime}$ and $3^{\prime}$ Modified dT Analogues}

The commercially available 1,2- $O$-isopropylidene- $\alpha$-D-xylofuranose (1, Scheme 1) was converted to 3-azido-ribofuranose 2 according to a literature procedure. ${ }^{[12]}$ Vorbrüggen $^{[13]}$ type coupling of $\mathbf{2}$ with silylated thymine, followed by alkaline deprotection afforded the azido nu- cleoside $3 \mathbf{a}^{[14]}$. After tritylation of the primary hydroxyl group, $3 \mathbf{a}^{[14]}$ was converted into the $2,2^{\prime}$-anhydro-analogue 4. ${ }^{[15]}$ Alkaline treatment of $\mathbf{4}$ yielded intermediate $\mathbf{5}$ with the 2 '-hydroxyl group in the arabino ("UP") configuration. ${ }^{[16]}$ Detritylation of $\mathbf{5}$ with $80 \%$ HOAc quantitatively yielded nucleoside $\mathbf{6 a}^{[17]}$. Nucleophilic chlorination of 4 with $4 \mathrm{M}$ $\mathrm{HCl}$ in dioxane ${ }^{[18]}$ resulted in the formation of 1 -( $3^{\prime}$-azido2 '-chloro-2', $3^{\prime}$-dideoxy-5- $O$-trityl- $\beta$-D-ribofuranosyl)thymine (7a). Analogue 5 was treated with $\operatorname{DAST}^{[19]}$ and, after detritylation, nicely afforded nucleoside $\mathbf{8 a}$ with the fluorine atom at the $2^{\prime}$-position of the sugar moiety in ribo ("DOWN") configuration. This approach towards the synthesis of 8a improved the methods previously described. [20] Selective triphenylphosphane reduction of the azido moieties of nucleosides $\mathbf{3} \mathbf{a}^{[14]}, \mathbf{6} \mathbf{a}^{[17]}, \mathbf{7 a}$ and $\mathbf{8 a}^{[20]}$ smoothly afforded the novel $3^{\prime}$-amine functionalised analogues $7 \mathbf{b}$ and $\mathbf{8 b}$ and the known $\mathbf{3} \mathbf{b}^{[21 a]}$ and $\mathbf{6} \mathbf{b}^{[21 b]}$.

\section{TMPKmt Affinity (Inhibition Studies)}

Results of the binding studies are presented in Table 1. The $3^{\prime}$-azido and $3^{\prime}$-amino substituents are intended for direct interaction with Asp 9. With the $2^{\prime}$-modifications we

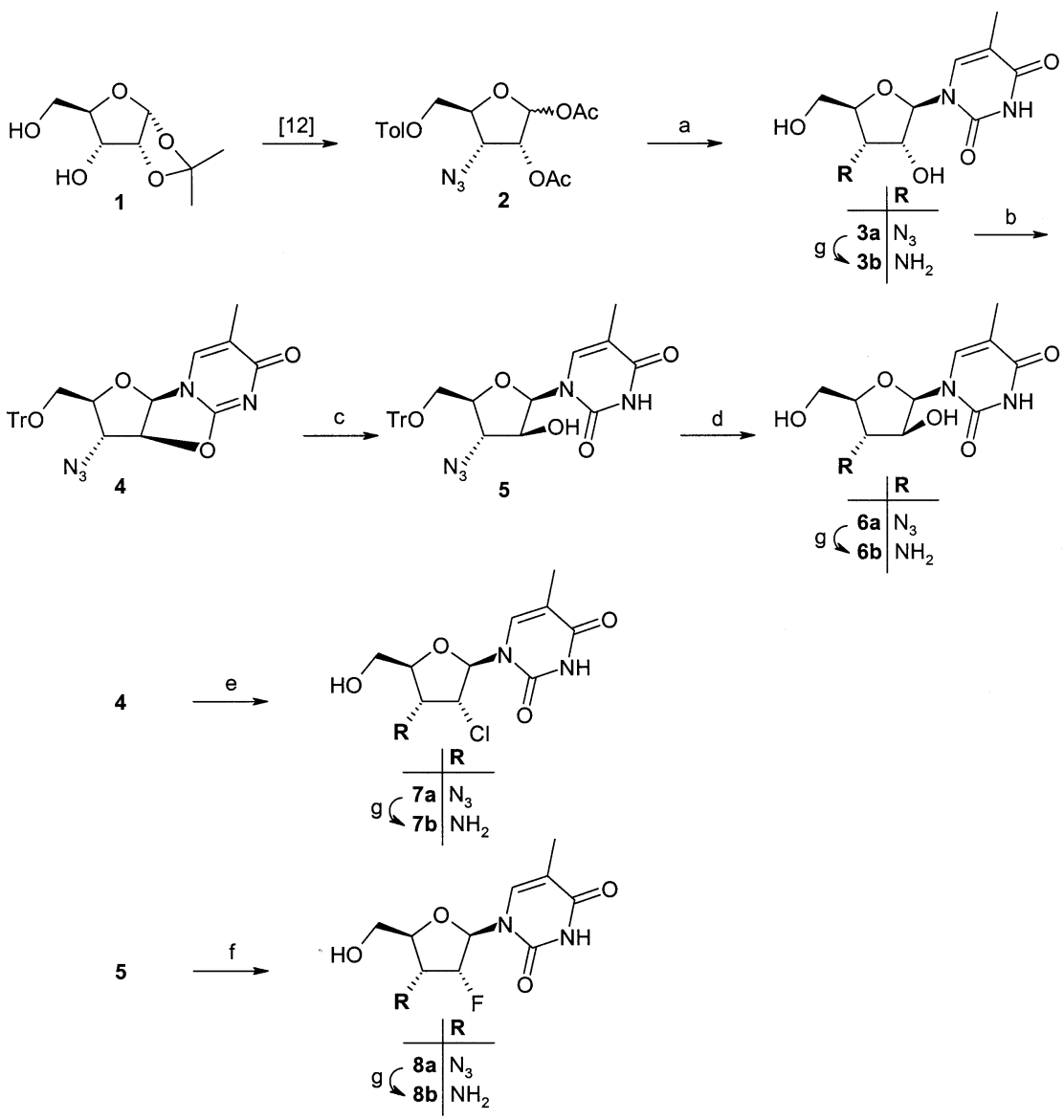

Scheme 1. Synthesis of $2^{\prime}$ - and $3^{\prime}$-modified thymidine nucleoside analogues: (a) (i) thymine, $\left[\left(\mathrm{CH}_{3}\right)_{3} \mathrm{Si}_{2} \mathrm{NH}_{2}\left(\mathrm{CH}_{3}\right)_{3} \mathrm{SiCl}_{2} \mathrm{CF}_{3} \mathrm{SO}_{2} \mathrm{OSiMe}_{3}\right.$, pyridine, 1,2-dichloroethane, room temp., (ii) $0.15 \mathrm{~N} \mathrm{NaOCH}_{3}$ in $\mathrm{MeOH}$, room temp., (iii) adjusted to $\mathrm{pH} \approx 7 \mathrm{with} \mathrm{H}_{2} \mathrm{O} / \mathrm{AcOH}(9: 1)$; (b) (i) triphenylmethyl chloride, pyridine, $65{ }^{\circ} \mathrm{C}, 48 \mathrm{~h}$, (ii) $\mathrm{CF}_{3} \mathrm{SO}_{2} \mathrm{Cl}, \mathrm{DMAP}, \mathrm{CH}_{2} \mathrm{Cl}_{2}, 4{ }^{\circ} \mathrm{C}$; (c) (i) $1 \mathrm{~N} \mathrm{NaOH}, \mathrm{EtOH} / \mathrm{H}_{2} \mathrm{O}$ (1:1), room temp., (ii) adjusted to $\mathrm{pH} \approx 7$ with $\mathrm{HOAc}$; (d) $80 \% \mathrm{CH}_{3} \mathrm{COOH}, 90{ }^{\circ} \mathrm{C}$; (e) $4 \mathrm{~m} \mathrm{HCl}$ in 1,4-dioxane; (f) (i) DAST, pyridine, tolueen, 50 ${ }^{\circ} \mathrm{C}$, (ii) $80 \% \mathrm{CH}_{3} \mathrm{COOH}, 90{ }^{\circ} \mathrm{C}$; (g) $\mathrm{Ph}_{3} \mathrm{P}, \mathrm{NH}_{4} \mathrm{OH}$, pyridine, room temp. 
explored if an $\alpha$-chloro or $\alpha$-fluoro substituent in the vicinity of Tyr103 would be sterically tolerated.

Table 1. Kinetic parameters of Mycobacterium tuberculosis thymidylate kinase with the 2 '- and 3 '-modified thymidine analogues

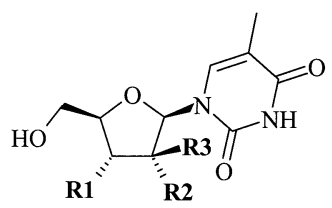

\begin{tabular}{llllr}
\hline Analogue & $\mathrm{R} 1$ & $\mathrm{R} 2$ & $\mathrm{R} 3$ & $K_{\mathrm{i}}[\mu \mathrm{M}]$ \\
\hline $\mathrm{dT}^{[9]}$ & $\mathrm{OH}$ & $\mathrm{H}$ & $\mathrm{H}$ & 27 \\
$\mathrm{AZT}^{[9]}$ & $\mathrm{N}_{3}$ & $\mathrm{H}$ & $\mathrm{H}$ & 28 \\
$\mathbf{3 a}$ & $\mathrm{N}_{3}$ & $\mathrm{OH}$ & $\mathrm{H}$ & 740 \\
$\mathbf{3 b}$ & $\mathrm{NH}_{2}$ & $\mathrm{OH}$ & $\mathrm{H}$ & 750 \\
$\mathbf{6}$ & $\mathrm{N}_{3}$ & $\mathrm{H}$ & $\mathrm{OH}$ & 215 \\
$\mathbf{6 b}$ & $\mathrm{NH}_{2}$ & $\mathrm{H}$ & $\mathrm{OH}$ & 1260 \\
$\mathbf{7 a}$ & $\mathrm{N}_{3}$ & $\mathrm{Cl}$ & $\mathrm{H}$ & 170 \\
$\mathbf{7 b}$ & $\mathrm{NH}_{2}$ & $\mathrm{Cl}$ & $\mathrm{H}$ & 145 \\
$\mathbf{8 a}$ & $\mathrm{N}_{3}$ & $\mathrm{~F}$ & $\mathrm{H}$ & 118 \\
$\mathbf{8 b}$ & $\mathrm{NH}_{2}$ & $\mathrm{~F}$ & $\mathrm{H}$ & 190 \\
\hline
\end{tabular}

As expected, the introduction of the 2 '-hydroxyl function in $\mathbf{3} \mathbf{a}$ and $\mathbf{3 b}$ had adverse effects on the affinity, due to an unfavourable interaction with the nearby tyrosine residue (Tyr103). Indeed, the affinity markedly improves when the $2^{\prime}$-hydroxyl adopts the opposite arabino configuration in 6 a $\left(K_{\mathrm{i}}=215 \mu \mathrm{M}\right)$, or when the $2^{\prime}$-ribo-hydroxyl (in $\left.\mathbf{3 a}-\mathbf{b}\right)$ is replaced by a chloro or fluoro atom in $7 \mathbf{a}-\mathbf{b}$ and $8 \mathbf{a}-\mathbf{b}$, respectively. The incorporation of a fluoro atom into the sugar moiety of nucleosides has great impact on the biological and chemical characteristics of these molecules. ${ }^{[22]}$ The strong electronegative fluorine alters the electronic properties of the molecule and specifically tunes the conformation of the furanose ring. ${ }^{[22 b][22 c]}$ Also, the $2^{\prime}-\alpha$-fluoro atom in $\mathbf{8 a}-\mathbf{b}$ isosterically replaces a hydrogen atom and is known to greatly enhance the stability of the glycosidic bond. ${ }^{[18]}$ Still, the affinity for $7 \mathbf{a}-\mathbf{b}$ and $\mathbf{8 a}-\mathbf{b}$ is moderate, i.e. $>100$ $\mu \mathrm{M}$. This was not expected, since earlier work suggested "to combine a $2^{\prime}$-chlorine and $3^{\prime}$-azido group". [10] Furthermore, the $3^{\prime}$-amino analogues $\mathbf{7 b}$ and $\mathbf{8 b}$, showed no enhanced TMPKmt affinity compared to their $3^{\prime}$-azido forms $\mathbf{7 a}$ and $\mathbf{8 a}$, indicating that the positively charged $3^{\prime}$-amine is not optimally oriented to form an ionic interaction with Asp9. These results prompted us to investigate the preferred puckering of the furanose ring of the $2^{\prime}$ - and $3^{\prime}$-modified $7 \mathbf{a}-\mathbf{b}$ and $\mathbf{8} \mathbf{a}-\mathbf{b}$ pairs.

\section{NMR Spectroscopy}

NMR spectroscopy in $\mathrm{D}_{2} \mathrm{O}$ permits extension of the results to the in vivo/ in vitro situation and was used for the pseudorotational analysis ${ }^{[23]}$ of nucleosides $7 \mathbf{a}-\mathbf{b}$ and $\mathbf{8 a}-\mathbf{b}$. The complete conformational analysis of a nucleoside (or nucleotide) usually comprises the determination of three principal structural parameters: (1) the glycosidic torsion angle $\chi$, which determines the syn or anti position of the base relative to the sugar moiety; (2) the torsion angle $\gamma$, which determines the orientation of the $5^{\prime}$-hydroxyl with respect to the $\mathrm{C}^{\prime}$; and (3) the puckering of the furanose ring and its deviation of planarity, described by the phase angle of pseudorotation $P\left(0-360^{\circ}\right)$ and the maximum outof-plane pucker $v_{\max }\left(30-46^{\circ}\right) .{ }^{[23]}$ Here, we only focussed on the latter, since (a) the ring puckering is known to be the main determinant in controlling the $\gamma$ - and $\chi$-angles; ${ }^{[24]}$ (b) most probably a strong preference for a specific $\mathrm{C}^{\prime}{ }^{\prime}-\mathrm{C} 5^{\prime}$ rotamer $(\gamma$-angle) is induced by the enzyme upon binding; and (c) as evidenced by the crystal structure data, ${ }^{[8]}$ TMPKmt binds its substrates with the base in the anti position ( $\chi$-angle).

In solution, the relative strengths and interplay of important anomeric and gauche effects ${ }^{[24,25]}$ drive the preference of the flexible furanose ring moiety of $N$-nucleosides between the north $(\mathrm{N})$ and south $(\mathrm{S})$ type puckered pseudorotamers. By convention, a phase angle $P=0^{\circ}$ corresponds to the absolute $\mathrm{N}$ conformation possessing a symmetrical twist form ${ }^{3} T_{2}\left(\mathrm{C}^{\prime}{ }^{\prime}\right.$-endo-C2'-exo), whereas the $\mathrm{S}$ antipode twist, ${ }^{2} T_{3}$ (C2'-endo-C3'-exo), is represented by $P=$ $180^{\circ} .^{[23]}$ Along the pseudorotational cycle, the conformation of the furanose ring alternates between envelope $(E)$ and twist $(T)$ conformations every $18^{\circ}$. We measured vicinal proton-proton coupling constants $\left({ }^{3} J_{1^{\prime}, 2^{\prime}},{ }^{3} J_{2^{\prime}, 3^{\prime}}\right.$, and $\left.{ }^{3} J_{3^{\prime}, 4^{\prime}}\right)$ of $7 \mathbf{a}-\mathbf{b}$ and $8 \mathbf{a}-\mathbf{b}$ at $500 \mathrm{MHz}$ in $\mathrm{D}_{2} \mathrm{O}$ (ca. $40 \mathrm{mM}$ ) in a $278-333 \mathrm{~K}$ range at $\mathrm{pD} 7.4$ (see Table 2).

Table 2. ${ }^{3} J_{\mathrm{H}, \mathrm{H}}$ coupling constants $[\mathrm{Hz}]$ and population of $\mathrm{S}$ conformers at five distinct temperatures in the range from 278 to $333 \mathrm{~K}$

\begin{tabular}{lrrrc}
\hline Temp. $[\mathrm{K}]$ & ${ }^{3} J_{1^{\prime}, 2^{\prime}}[\mathrm{a}]$ & ${ }^{3} J_{2^{\prime}, 3^{\prime}}$ & ${ }^{3} J_{3^{\prime}, 4^{\prime}}$ & $X_{\mathrm{S}}[\%]^{[\mathrm{b}]}$ \\
\hline $\mathbf{7 a}$ & & & & \\
278 & 4.70 & 5.55 & 6.21 & 45 \\
288 & 4.76 & 5.59 & 6.25 & 45 \\
300 & 4.92 & 5.61 & 6.39 & 46 \\
318 & 5.06 & 5.63 & 6.43 & 47 \\
333 & 5.20 & 5.67 & 6.49 & 48 \\
$7 \mathbf{b}$ & & & & \\
278 & 2.12 & 4.93 & 8.17 & 16 \\
288 & 2.30 & 4.94 & 8.11 & 17 \\
300 & 2.50 & 4.94 & 7.91 & 20 \\
318 & 2.66 & 4.95 & 7.80 & 21 \\
333 & 2.69 & 4.95 & 7.73 & 22 \\
$\mathbf{8 a}$ & & & & \\
278 & 1.27 & 4.73 & 9.31 & 3 \\
288 & 1.54 & 4.78 & 9.24 & 5 \\
300 & 1.66 & 4.81 & 9.19 & 7 \\
318 & 1.69 & 4.88 & 9.07 & 8 \\
333 & 1.72 & 4.89 & 9.05 & 8 \\
$\mathbf{8 b}$ & & & & \\
278 & $\leq 1.00$ & 4.30 & 9.70 & $\leq 1$ \\
288 & $\leq 1.00$ & 4.49 & 9.92 & $\leq 1$ \\
300 & $\leq 1.00$ & 4.79 & 9.97 & $\leq 1$ \\
318 & $\leq 1.00$ & 4.81 & 10.01 & $\leq 1$ \\
333 & $\leq 1.00$ & 4.82 & 10.07 & $\leq 1$ \\
\hline
\end{tabular}

[a] ${ }^{3} J_{\mathrm{H}, \mathrm{H}}$ recorded at $500 \mathrm{MHz}$ in $\mathrm{D}_{2} \mathrm{O}$ at $\mathrm{pD} 7.4$. ${ }^{[\mathrm{b}]}$ The PSEUROT program (version 6.2$)^{[26]}$ has been used to derive populations as well as geometries of $\mathrm{N}$ and $\mathrm{S}$ coformers (see Table 3 ) at stated temperature. 
Subsequently, we used the computer program PSEUROT $6.2^{[26]}$ to calculate, at each temperature interval, the best fit of five conformational parameters, i.e. $P$ and $v_{\max }$ for both $\mathrm{N}$ and $\mathrm{S}$ conformers and the mole fraction of $\mathrm{S}\left(X_{\mathrm{S}}\right)$, based on the three experimental coupling constants (see Tables 2 and 3).

Table 3. Optimized pseudorotational parameters and errors of pseudorotational analysis ${ }^{[a]}$ based on ${ }^{3} J_{\mathrm{H}, \mathrm{H}}$ measured at five distinct temperatures in the range of 278 to $333 \mathrm{~K}$

\begin{tabular}{llllll}
\hline Analogue & $\begin{array}{l}P_{\mathrm{N}} \\
{[\mathrm{deg}]}\end{array}$ & $\begin{array}{l}v_{\max , \mathrm{N}} \\
{[\mathrm{deg}]}\end{array}$ & $\begin{array}{l}P_{\mathrm{S}} \\
{[\mathrm{deg}]}\end{array}$ & $\begin{array}{l}v_{\max , \mathrm{S}} \\
{[\mathrm{deg}]}\end{array}$ & $\begin{array}{l}\mathrm{rms} \\
{[\mathrm{Hz}]^{[\mathrm{b}]}}\end{array}$ \\
\hline $\mathbf{7 a}$ & -2.7 & 37.5 & 132.7 & 38.8 & 0.110 \\
$\mathbf{7 b}$ & 7.7 & 38.4 & 162.7 & 38.2 & 0.020 \\
$\mathbf{8 a}$ & 28.7 & 34.6 & $146.1^{[\mathrm{c}]}$ & $36.0^{[\mathrm{c}]}$ & 0.042 \\
$\mathbf{8 b}$ & 31.2 & 36.5 & $151.8^{[\mathrm{c}]}$ & $30.0^{[\mathrm{c}]}$ & 0.172 \\
\hline
\end{tabular}

[a] The least-squares minimization program PSEUROT (version $6.2)^{[26]}$ has been used for ${ }^{3} J_{\mathrm{H}, \mathrm{H}}$ and equilibrium populations of $\mathrm{N} \rightleftarrows \mathrm{S}$ equilibrium at various temperatures see Table 2 . ${ }^{[\mathrm{b}]}$ The $\mathrm{rms}$ deviation represents the deviation of calculated and experimental ${ }^{3} J_{\mathrm{H}, \mathrm{H}}: \mathrm{rms}=\left\{1 / n \Sigma\left[J_{\mathrm{i}}^{\text {expt }}-J_{\mathrm{i}}^{\text {theor }}\left(P_{\mathrm{N}}, \tilde{\mathrm{v}}_{\max , \mathrm{N}}, P_{\mathrm{S}}, \tilde{\mathrm{v}}_{\max , \mathrm{S}}\right)\right]^{2}\right\}^{1 / 2} \cdot{ }^{[\mathrm{c}]}$ The pseudorotational parameter was kept fixed during optimisation.

The preferred solution state conformation of $\mathbf{7 a}, \mathbf{7 b}, \mathbf{8 a}$, and $\mathbf{8 b}$ is determined by a variety of factors, but is primarily influenced by the class and positioning of the $2^{\prime}$ - and $3^{\prime}$ substituents and the complex interplay of the resulting four gauche interactions, i.e. $\quad \mathrm{O}^{\prime}-\mathrm{C}^{\prime}-\mathrm{C} 3^{\prime}-\mathrm{R} 3$, $\mathrm{O} 4^{\prime}-\mathrm{C} 1^{\prime}-\mathrm{C} 2^{\prime}-\mathrm{R} 2, \quad \mathrm{R} 2-\mathrm{C}^{\prime}-\mathrm{C} 3^{\prime}-\mathrm{R} 3, \quad$ and $\mathrm{N} 1-\mathrm{C}^{\prime}-\mathrm{C} 2^{\prime}-\mathrm{R} 2$. The mole fraction of $\mathrm{S}$ at $30{ }^{\circ} \mathrm{C}\left(X_{\mathrm{S}}\right)$ shows these analogues prefer the "northern" type ring puckering (see Table 4). In combination with the $3^{\prime}$-azide modification, the $2^{\prime}$-chloro derivative $7 \mathbf{a}\left(P_{\mathrm{N}}=-2.7^{\circ}\right.$, $\left.v_{\text {max }, \mathrm{N}}=37.5^{\circ}\right)$ virtually adopts a ${ }^{3} T_{2}\left(\mathrm{C} 3^{\prime}\right.$-endo-C2'-exo twist) conformation, whereas the $2^{\prime}$-fluoro analogue $8 \mathbf{a}$ $\left(P_{\mathrm{N}}=28.7^{\circ}, v_{\max , \mathrm{N}}=34.6^{\circ}\right)$ exhibits a conformation that lies between a ${ }^{3} E$ (C3'-endo envelope) and ${ }^{3} T_{4}\left(\mathrm{C}^{\prime}\right.$-endo$\mathrm{C} 4{ }^{\prime}$-exo twist). For the $3^{\prime}$-amino modified compounds, the puckering of the $2^{\prime}$-chloro derivative $7 \mathbf{b}\left(P_{\mathrm{N}}=7.7^{\circ}\right.$, $\left.v_{\text {max }, \mathrm{N}}=38.4^{\circ}\right)$, is in between a ${ }^{3} T_{2}\left(\mathrm{C}^{\prime}{ }^{\prime}\right.$-endo-C2'-exo twist) and ${ }^{3} E$ (C3'-endo envelope), whereas the $2^{\prime}$-fluoro derivative $8 \mathbf{b}\left(P_{\mathrm{N}}=31.2^{\circ}, v_{\max , \mathrm{N}}=36.5^{\circ}\right)$ is close to a ${ }^{3} T_{4}$ (C3'-endo-C4'-exo twist). Our results show that when $3^{\prime}$ azido/amino and $2^{\prime}$-chloro/fluoro modifications are combined, the pseudo-axial position of the $2^{\prime}$-halogens and the resulting $\mathrm{O}^{\prime}-\mathrm{C}^{\prime}-\mathrm{C}^{\prime}-\mathrm{R} 2$ gauche effect are directing the furanose ring towards the "northern" hemisphere of the pseudorotational circle. This $\mathrm{O} 4^{\prime}-\mathrm{C}^{\prime}{ }^{\prime}-\mathrm{C} 2^{\prime}-\mathrm{R} 2$ gauche interaction and its drive towards the $\mathrm{N}$-type conformers is cooperative with the anomeric effect ${ }^{[25]}$ and, as evidenced by the $X_{\mathrm{S}}$-values of $7 \mathbf{a}-\mathbf{b}(\leq 46 \%)$ vs. $8 \mathbf{a}-\mathbf{b}(\leq 6 \%)$ (see Table 4), relates to the electronegativity of the $2^{\prime}$-substituents. This is in line with previous findings. ${ }^{[22 c, 27]}$ Marquez et al. ${ }^{[22 c]}$ proved the pseudorotational equilibrium to be governed by the $\alpha$ - or $\beta$-oriented fluorine atoms in $2^{\prime}$ - or $3^{\prime}$ position and their tendency to adopt a pseudo-axial orien- tation. Furthermore, the comparative solution conformation analysis of both $3^{\prime}$ - $\alpha$-fluorothymidine (FLT) and AZT clearly demonstrated that the small, electronegative $3^{\prime}$-fluorine atom was practically locked in the pseudo-axial position (due to the strong $\mathrm{O}^{\prime}-\mathrm{C}^{\prime}-\mathrm{C}^{\prime}-\mathrm{F}$ gauche interaction), whereas the sterically larger $3^{\prime}$-azide showed no clear positional preference. ${ }^{[22 \mathrm{~b}]}$ Here, however, without proper energetic quantification of the various stereoelectronic effects in $7 \mathbf{a}-\mathbf{b}$ and $\mathbf{8 a}-\mathbf{b}$, we can only postulate that the $\mathrm{O} 4^{\prime}-\mathrm{C}^{\prime}-\mathrm{C} 2^{\prime}-\mathrm{Cl} / \mathrm{F}$ gauche effect dominates the opposite $\mathrm{O} 4^{\prime}-\mathrm{C} 4^{\prime}-\mathrm{C}^{\prime}{ }^{\prime}-\mathrm{N}_{3} / \mathrm{NH}_{2}$ gauche effect and decreases as size increases and/or electronegativity decreases (cf. $7 \mathbf{a}-\mathbf{b}$ vs. $\mathbf{8 a}-\mathbf{b}$ ). Only the S-type conformers of $7 \mathbf{a}$ and $\mathbf{7 b}$ are relevant (for, 8a-b $X_{\mathrm{S}} \leq 6 \%$ ). The $2^{\prime}$-chloro-3'-azido modified $7 \mathbf{a}\left(P_{\mathrm{S}}=132.7^{\circ}, v_{\max , \mathrm{N}}=36.5^{\circ}\right)$ has a conformation in between a ${ }^{1} E$ ( $\mathrm{Cl}^{\prime}$-exo envelope $)$ and ${ }^{2} T_{1}\left(\mathrm{C} 2^{\prime}\right.$-endo- $\mathrm{Cl}^{\prime}$ exo twist), whereas the $3^{\prime}$-amino derivative $7 \mathbf{b}\left(P_{\mathrm{S}}=162.7^{\circ}\right.$, $\left.v_{\max , \mathrm{N}}=36.5^{\circ}\right)$ has a perfect ${ }^{2} E\left(\mathrm{C} 2^{\prime}\right.$-endo envelope $) \mathrm{S}$ type conformation.

X-ray crystallographic analysis of TMPKmt complexed dTMP shows that the furanose ring of the substrate is biased towards the "south". ${ }^{[8,10]}$ The preference of $7 \mathbf{a}-\mathbf{b}$ and $\mathbf{8 a}-\mathbf{b}$ for the opposite "northern" conformation results in the pseudo-equatorial positioning of the 3 '-azide/amine and can explain their moderate affinity for TMPKmt. The $3^{\prime}$ hydroxyl function of dTMP interacts directly with an aspartate residue (Asp9) in the TMPKmt binding site. ${ }^{[8]}$ The positional shift of the $3^{\prime}$-azido/amino substituents, when puckered in $\mathrm{N}$, might result in an ineffective contact with this Asp9 and hence lower the affinity. The introduction of a methylene spacer between the 3 '-azido/amino group and the $\mathrm{C}^{3}$ ', the so-called "branched chain", might restore the hampered interaction with Asp9 and consequently improve the affinity.

\section{$\mathrm{N} \rightleftarrows \mathrm{S}$ Energy Calculations}

Generally, in the solid state, mainly influenced by crystal packing forces, ${ }^{[28]}$ only one of the two solution conformations $\left(\mathrm{N}\right.$ or $\mathrm{S}$ ) is present. ${ }^{[24]}$ Similarly, when a nucleoside (or nucleotide) binds to its target only one form is expected to be present. Although the $\mathrm{N} \rightleftarrows \mathrm{S}$ energy difference is about $4 \mathrm{kcal} / \mathrm{mol}$ for classic nucleosides and nucleotides, ${ }^{[24]}$ it can explain their differences in binding affinity. ${ }^{[29]}$ We estimated the enthalpy $\left(\Delta H^{\circ}\right)$ and the entropy $\left(\Delta S^{\circ}\right)$ of the $\mathrm{N} \rightleftarrows \mathrm{S}$ twostate pseudorotational equilibrium for $7 \mathbf{a}-\mathbf{b}$ and $\mathbf{8 a}-\mathbf{b}$ from the slopes and intercepts of the van't Hoff plots $\left[\ln \left(X_{\mathrm{S}} /\right.\right.$ $X_{\mathrm{N}}$ ) vs. $\left.1 / T\right]$ (see Table 4 ). The signs of the thermodynamic parameters $\left(\Delta H^{\circ}, \Delta S^{\circ}\right.$, and $\left.\Delta G^{\circ}\right)$ are arbitrary chosen so that positive values indicate the drive of $\mathrm{N} \rightleftarrows \mathrm{S}$ equilibrium to $\mathrm{N}$, as is the case for $\mathbf{7 a}-\mathbf{b}$ and $\mathbf{8 a}-\mathbf{b}$, whereas negative values would describe the drive towards $\mathrm{S}$.

Note that at $30^{\circ} \mathrm{C}$ the $\Delta H^{\circ}$ and $\Delta S^{\circ}$ contributions to the $\Delta G^{\circ}$ of the pseudorotational equilibrium in $7 \mathbf{a}-\mathbf{b}$ and $\mathbf{8 a}-\mathbf{b}$ are quite different and that it is the significant $\Delta H^{\circ}$ contribution that drives the pseudorotational equilibrium to the "north". Although the $\Delta G^{\circ}$-values for $7 \mathbf{a}$ and $7 \mathbf{b}$ are positive, their $\Delta H^{\circ}$ contribution to $\Delta G^{\circ}$ is rather low $(1.8 \mathrm{~kJ} /$ mol and $5.7 \mathrm{~kJ} / \mathrm{mol}$ respectively) and indicates the $\mathrm{N} \rightleftarrows \mathrm{S}$ 
Table 4. Values for $\Delta H^{\circ}$ and $\Delta S^{\circ}$ of the $\mathrm{N} \rightleftarrows \mathrm{S}$ conformational equilibria as obtained through van't Hoff plots, $\Delta G^{\circ}$, and population of the $\mathrm{S}$ conformer at $303 \mathrm{~K}$

\begin{tabular}{lcccc}
\hline Analogue & $\begin{array}{c}\Delta H^{[\mathrm{a}]} \\
{[\mathrm{kJ} / \mathrm{mol}]}\end{array}$ & $\begin{array}{l}\Delta S^{[\mathrm{a}]} \\
{[\mathrm{J} / \mathrm{mol} \mathrm{K}]}\end{array}$ & $\begin{array}{l}\Delta G^{[\mathrm{b}]} \\
{[\mathrm{kJ} / \mathrm{mol}]}\end{array}$ & $X_{\mathrm{S}}^{[\mathrm{c}]}[\%]$ \\
\hline 7a & 1.8 & 4.6 & 0.38 & 46 \\
$\mathbf{7 b}$ & 5.7 & 6.8 & 3.6 & 19 \\
$\mathbf{8 a}$ & 13.7 & 22.4 & 7.0 & 6 \\
$\mathbf{8 b}$ & 21.1 & 1.2 & 20.7 & $\leq 1$ \\
\hline
\end{tabular}

[a] $\Delta H^{\circ}$ and $\Delta S^{\circ}$ were calculated from the slope and intercept of the line obtained through the least-squares fitting procedure of $\ln$ $\left(X_{\mathrm{S}} / X_{\mathrm{N}}\right)$ to the reciprocal of temperature: $\ln \left(X_{\mathrm{S}} / X_{\mathrm{N}}\right)=-\left(\Delta H^{\circ} /\right.$ $R) \cdot(1 / T)+\left(\Delta S^{\circ} / R\right) . R$ is the gas constant $(8.31 \mathrm{~J} / \mathrm{mol} \cdot \mathrm{K}){ }^{[\mathrm{b}]}$ Calculated Gibbs free energy at $303 \mathrm{~K}\left(\Delta G^{\circ}=\Delta H^{\circ}-T \Delta S^{\circ}\right)$. ${ }^{[c]}$ The population of the $\mathrm{S}$ conformer at $303 \mathrm{~K}$ through the relation $X_{\mathrm{S}} /$ $X_{\mathrm{N}}=K=\exp \left(-\Delta G^{303} / R T\right)$.

equilibrium can be easily driven towards $\mathrm{S}$ by the enzyme upon binding. More likely, their rather poor affinity, i.e. $K_{\mathrm{i}} \approx 150 \mu \mathrm{M}$ (see Table 1), results from the steric clash between the larger $2^{\prime}$ - $\alpha$-chloro atom with Tyr103. In case of $7 \mathbf{a}-\mathbf{b}$ however, this effect is not so dramatic as for the $2^{\prime}$ $\alpha$-hydroxyl in $\mathbf{3} \mathbf{a}-\mathbf{b}$, which probably relates to the greater hydrophobicity of the chloro atom. The $\Delta H^{\circ}$ contributions of $\mathbf{8 a}$ and $\mathbf{8 b}(13.7 \mathrm{~kJ} / \mathrm{mol}$ and $21.1 \mathrm{~kJ} / \mathrm{mol}$ respectively), on the other hand, suggest that the $\mathrm{N} \rightleftarrows \mathrm{S}$ equilibrium is strongly biased towards $\mathrm{N}$, the antipodal conformation of the $\mathrm{S}$ puckering preferred by TMPKmt. ${ }^{[8]}$ Such an energy gap might not easily be overcome by TMPKmt and, together with the uneffective pseudo-equatorial position of the $3^{\prime}$-azide/amine, plausibly accounts for the moderate $K_{\mathrm{i}}$ values of $\mathbf{8 a}$ and $\mathbf{8 b}$. This conformational rigidity of $\mathbf{8 a}$ is also a possible explanation for the lack of anti-HIV-1 activity. ${ }^{[20 b]}$ The strong tendency of $8 \mathbf{a}$ to adopt a N-type puckering probably hampers the activation of this nucleoside to its triphosphate counterpart by cellular kinases, known to prefer $\mathrm{S}$ conformers as substrates. ${ }^{[30]}$

\section{Conclusion}

In search for new treatment strategies against tuberculosis, Mycobacterium tuberculosis thymidine monophosphate kinase (TMPKmt) was previously introduced as a potential target for the rational design of inhibitors. Stimulated by the fact that thymidine and $3^{\prime}$ - $\alpha$-azido-thymidine proved to be potent inhibitors, we further elaborated our research towards the rational design of new leads based on the TMPKmt crystal structure. This work describes the synthesis and biological evaluation of a number of $2^{\prime}$-and $3^{\prime}$ modified thymidine analogues $(\mathbf{3} \mathbf{a}-\mathbf{b}, \mathbf{6} \mathbf{a}-\mathbf{b}, \mathbf{7} \mathbf{a}-\mathbf{b}$, and 8a-b).

As expected the combination of $3^{\prime}$-azide/amine and $2^{\prime}-\alpha /$ $\beta$-hydroxyl substitutions, i.e. for $\mathbf{3 a}-\mathbf{b}$ and $\mathbf{6 a}-\mathbf{b}$, decreased the affinity significantly due to interaction with a tyrosine residue (Tyr103) known to be in the vicinity of the $2^{\prime}$-position. To our surprise the combination of $3^{\prime}$-azide/amine and $2^{\prime}$-chloro/fluoro substituents $(\mathbf{7 a}-\mathbf{b}$ and $\mathbf{8 a}-\mathbf{b})$, known to be beneficial for the TMPKmt affinity when introduced separately, only resulted in moderate binding properties. This prompted us to investigate the conformational aspects of these thymidine analogues. In solution the sugar ring of nucleosides and nucleotides is known to exist in a rapid dynamic equilibrium, between the extreme "northern" $(\mathrm{N})$ and the opposite "southern" (S) conformations. When a nucleoside or a nucleotide binds to its target enzyme, like in the crystal, only one of the two solution conformations is expected to be present in the active site. Through the NMR spectral parameters of $\mathbf{7 a}-\mathbf{b}$ and $\mathbf{8 a}-\mathbf{b}$, i.e. vicinal coupling constants $\left({ }^{3} J_{\mathrm{H}, \mathrm{H}}\right)$, and their subsequent analysis with the PSEUROT program we indicated these analogues to be biased strongly towards the $\mathrm{N}$ conformation of the furanose ring. Via van't Hoff plots we also calculated the energy $\left(\Delta H^{\circ}, \Delta S^{\circ}\right.$ and the resulting $\Delta G^{\circ}$ ) for the $\mathrm{N} \rightleftarrows \mathrm{S}$ equilibria of $7 \mathbf{a}-\mathbf{b}$ and $8 \mathbf{a}-\mathbf{b}$. Keeping the binding affinity of these derivatives in mind, our conformational analysis and energy calculations show to have important implications on: $(i)$ the appropriate positioning of the $2^{\prime}$ - and $3^{\prime}$ - substituents; (ii) the ability of the enzyme to induce an S-type puckering on its ligand.

The discrepancy between the conformation of the substrate from the target X-ray structure and the solution state conformation of the analogues examined, indicates the danger of only using crystal structural data for the formulation of structure-activity relationships. These findings will allow us to further rationally design other $2^{\prime}$ - and $3^{\prime}$-modified thymidine analogues, considering the influence of the planned modification (in, 2' - and $3^{\prime}$-position) on both potential binding interactions and conformational preference.

\section{Experimental Section}

General Remarks: ${ }^{1} \mathrm{H}$ and ${ }^{13} \mathrm{C}$ spectra were obtained with a Varian $300 \mathrm{MHz}$ spectrometer $\left({ }^{1} \mathrm{H}\right.$ NMR: $300 \mathrm{MHz} .{ }^{13} \mathrm{C}$ NMR: $\left.75 \mathrm{MHz}\right)$. The residual solvent signal of $\left[\mathrm{D}_{6}\right] \mathrm{DMSO}$ was used as a secondary reference. Assignment of all ${ }^{1} \mathrm{H}$-resonances was confirmed by 2D ${ }^{1} \mathrm{H}-{ }^{1} \mathrm{H}$ COSY experiments. The signals assigned to amino and hydroxyl groups were exchangeable with $\mathrm{D}_{2} \mathrm{O}$. Abbreviations used are $\mathrm{s}=$ singlet, $\mathrm{d}=$ doublet, $\mathrm{t}=$ triplet, $\mathrm{q}=$ quadruplet, $\mathrm{m}=$ multiplet, $\mathrm{dd}=$ double of doublets, app $=$ apparent, and $\mathrm{br}=$ broad signal. Coupling constants $(J)$ are expressed in Hz. Exact mass measurements were performed on a quadrupole/orthogonal-acceleration time-of-flight (Q/oaTOF) tandem mass spectrometer (qTOF 2, Micromass, Manchester, UK) equipped with a standard electrospray ionisation (ESI) interface. Samples were infused in a 2-propanol/water (1:1) mixture at $3 \mu \mathrm{L} / \mathrm{min}$. Precoated Macherey-Nagel \& Co., ALUGRAM ${ }^{\circledR}$ SIL G/UV 254 silica gel plates were used for TLC and spots were examined with UV-light at $254 \mathrm{~nm}$ and/or a sulfuric acid-anisaldehyde solution or a ninhydrin $(0.5 \%$ in EtOH) solution. Column chromatography was performed on silica gel $560(0.06-0.2 \mathrm{~mm})$ from Uetikon Chemie. 1,2$O$-isopropylidene- $\alpha$-D-xylofuranose (1), reagents, anhydrous $\mathrm{Et}_{2} \mathrm{O}$, pyridine and toluene were purchased from ACROS ORGANICS. $\mathrm{CH}_{2} \mathrm{Cl}_{2}, \mathrm{ClCH}_{2} \mathrm{CH}_{2} \mathrm{Cl}$ and $\mathrm{MeOH}$ were obtained by distillation after refluxing overnight on $\mathrm{CaH}_{2}$.

1,2-Di- $O$-Acetyl-3-azido-5- $O$-(4-methylbenzoyl)-3-deoxy- $\beta$-D-ribofuranose (2): According to ref. ${ }^{[12 b]}$ Exact mass (ESI-MS, $i \mathrm{Pr}-$ 
$\mathrm{OH}: \mathrm{H}_{2} \mathrm{O}$ ) calculated for $\mathrm{C}_{17} \mathrm{H}_{19} \mathrm{~N}_{3} \mathrm{O}_{7} \mathrm{Na}[\mathrm{M}+\mathrm{Na}]^{+}$400.1120; found 400.1198 .

1-(3-Azido-3-deoxy-p-D-ribofuranosyl)thymine (3a): A mixture of thymine $(838 \mathrm{mg}, 6.7 \mathrm{mmol})$ in hexamethyldisilazane $(120 \mathrm{~mL})$, chlorotrimethylsilane $(0.85 \mathrm{~mL})$, and dry pyridine $(12 \mathrm{~mL})$ was refluxed overnight. After evaporation in vacuo, 2 ( $2.1 \mathrm{~g}, 5.5 \mathrm{mmol})$ in dry 1,2-dichloroethane $(50 \mathrm{~mL})$ and trimethylsilyl trifluoromethanesulfonate $(1.2 \mathrm{~mL}, 6.7 \mathrm{mmol})$ were added to the residue. After $5 \mathrm{~h}, \mathrm{CH}_{2} \mathrm{Cl}_{2}(50 \mathrm{~mL})$ and cooled $7 \% \mathrm{NaHCO}_{3}$ solution $(100 \mathrm{~mL})$ were added to the reaction mixture. The organic layer was separated, washed twice with $\mathrm{H}_{2} \mathrm{O}(100 \mathrm{~mL})$, dried with $\mathrm{MgSO}_{4}$, filtered, and the solvents evaporated to dryness. The residue was dissolved in $0.15 \mathrm{~N} \mathrm{NaOCH}_{3}$ in $\mathrm{CH}_{3} \mathrm{OH}(100 \mathrm{~mL})$, stirred for $1 \mathrm{~h}$, and neutralised with a $\mathrm{H}_{2} \mathrm{O} / \mathrm{CH}_{3} \mathrm{COOH}(9: 1)$ solution. The mixture was evaporated in vacuo, purified by column chromatography $\left(\mathrm{CH}_{2} \mathrm{Cl}_{2} /\right.$ $\mathrm{MeOH}, 95: 5)$ and crystallised from $\mathrm{CH}_{3} \mathrm{OH}$ to yield $1.52 \mathrm{~g}(80 \%)$ of the title compound 3a. ${ }^{1} \mathrm{H}$ NMR $\left(300 \mathrm{MHz},\left[\mathrm{D}_{6}\right] \mathrm{DMSO}\right): \delta=$ $1.77\left[\mathrm{~d},{ }^{4} \mathrm{~J}=1.2 \mathrm{~Hz}, 3 \mathrm{H}, \mathrm{C}(5)-\mathrm{CH}_{3}\right], 3.54\left[\mathrm{dd},{ }^{3} \mathrm{~J}=3.2 \mathrm{~Hz}\right.$ and $\left.{ }^{2} J_{5 \mathrm{a},}, 5 \mathrm{~b},=-12.3 \mathrm{~Hz}, 1 \mathrm{H}, \mathrm{C}\left(5^{\prime}\right)-\mathrm{H}_{\mathrm{b}}\right], 3.63\left[\mathrm{dd},{ }^{3} \mathrm{~J}=3.0 \mathrm{~Hz}, 1 \mathrm{H}\right.$, $\mathrm{C}\left(5^{\prime}\right)-\mathrm{H}_{\mathrm{a}}$ ], $3.84\left[\mathrm{q},{ }^{3} J=3.3 \mathrm{~Hz}\right.$ and ${ }^{3} J=7.8 \mathrm{~Hz}, 1 \mathrm{H}, \mathrm{C}\left(4^{\prime}\right)-\mathrm{H}$, $4.06\left[\operatorname{app~t},{ }^{3} J=5.1 \mathrm{~Hz}, 1 \mathrm{H}, \mathrm{C}\left(3^{\prime}\right)-\mathrm{H}\right], 4.40\left[\mathrm{t},{ }^{3} J=5.7 \mathrm{~Hz}, 1 \mathrm{H}\right.$, $\mathrm{C}\left(2^{\prime}\right)-\mathrm{H}$ ], 5.29 [br. s, $\left.1 \mathrm{H}, \mathrm{C}\left(5^{\prime}\right)-\mathrm{OH}\right], 5.74\left[\mathrm{~d},{ }^{3} \mathrm{~J}=5.7 \mathrm{~Hz}, 1 \mathrm{H}\right.$, $\mathrm{C}\left(1^{\prime}\right)-\mathrm{H}$ ], 6.13 [br. s, $1 \mathrm{H}, \mathrm{C}\left(2^{\prime}\right)-\mathrm{OH}$ ], $7.69\left[\mathrm{~d},{ }^{4} j=1.2 \mathrm{~Hz}, 1 \mathrm{H}\right.$, $\mathrm{C}(6)-\mathrm{H}$ ], 11.35 [br. s, $1 \mathrm{H}, \mathrm{N}(3)-\mathrm{H}] \mathrm{ppm} .{ }^{13} \mathrm{C} \mathrm{NMR}(75 \mathrm{MHz}$, $\left.\left[\mathrm{D}_{6}\right] \mathrm{DMSO}\right): \delta=12.85,61.50,61.81,74.37,82.44,88.27,110.16$, 136.77, 151.41, 164.34 ppm. Exact mass (ESI-MS, $i \operatorname{PrOH}: \mathrm{H}_{2} \mathrm{O}$ ) calculated for $\mathrm{C}_{10} \mathrm{H}_{13} \mathrm{~N}_{5} \mathrm{O}_{5} \mathrm{Na}[\mathrm{M}+\mathrm{Na}]^{+}$306.0814; found 306.0798 .

$O-2,2$ ' -Anhydro-1-(3-azido-3-deoxy-5- $O$-trityl- $\beta$-D-arabinofuranosyl)hymine (4): (1.43 g, $5.1 \mathrm{mmol})$ of 3a and trityl chloride (1.55 g, $5.6 \mathrm{mmol})$ were dissolved in dry pyridine $(15 \mathrm{~mL})$. The reaction mixture was heated at $65^{\circ} \mathrm{C}$ for 7 hours, stirred overnight at room temperature and the solvents evaporated to dryness. The residue was dissolved in $\mathrm{CH}_{2} \mathrm{Cl}_{2}(150 \mathrm{~mL})$ and washed subsequently with $7 \% \mathrm{NaHCO}_{3}$ solution $(150 \mathrm{~mL})$ and water $(150 \mathrm{~mL})$. The organic layer was dried with $\mathrm{MgSO}_{4}$, filtered, and the solvents evaporated to dryness. The residue was chromatographed on a silica gel column prepared in $\mathrm{CH}_{2} \mathrm{Cl}_{2} / \mathrm{MeOH}$ (99:1) and eluted with $\mathrm{CH}_{2} \mathrm{Cl}_{2}$ / $\mathrm{MeOH}(97: 3)$ to give $2.46 \mathrm{~g}(92.7 \%)$ of 1-(3-azido-3-deoxy-5-Otrityl- $\beta$-D-ribofuranosyl)thymine: $\quad{ }^{1} \mathrm{H} \quad \mathrm{NMR} \quad(300 \mathrm{MHz}$, [D $\mathrm{D}_{6}$ DMSO): $\delta=1.42\left[\mathrm{~d},{ }^{4} J=0.9 \mathrm{~Hz}, 3 \mathrm{H}, \mathrm{C}(5)-\mathrm{CH}_{3}\right], 3.19$ [dd, ${ }^{3} J=2.9 \mathrm{~Hz}$ and ${ }^{2} J_{5 \mathrm{a}^{\prime}, 5 \mathrm{~b}},=-11.0 \mathrm{~Hz}, 1 \mathrm{H}, \mathrm{C}\left(5^{\prime}\right)-\mathrm{H}_{\mathrm{b}}$ ], 3.29 [dd, ${ }^{3} J=3.8 \mathrm{~Hz}, 1 \mathrm{H}, \mathrm{C}\left(5^{\prime}\right)-\mathrm{H}_{\mathrm{a}}$ ] $3.97\left[\mathrm{~m}, 1 \mathrm{H}, \mathrm{C}\left(4^{\prime}\right)-\mathrm{H}\right], 4.30\left[\mathrm{q},{ }^{3} J=\right.$ $5.4 \mathrm{~Hz}$ and $\left.{ }^{3} J=10.8 \mathrm{~Hz}, 1 \mathrm{H}, \mathrm{C}\left(3^{\prime}\right)-\mathrm{H}\right], 4.57\left[\mathrm{q},{ }^{3} J=5.0 \mathrm{~Hz}\right.$ and $\left.{ }^{3} J=10.1 \mathrm{~Hz}, 1 \mathrm{H}, \mathrm{C}\left(2^{\prime}\right)-\mathrm{H}\right], 5.76\left[\mathrm{~d},{ }^{3} J=5.4 \mathrm{~Hz}, 1 \mathrm{H}, \mathrm{C}\left(1^{\prime}\right)-\mathrm{H}\right]$, $6.24\left[\mathrm{~d},{ }^{3} J=4.8 \mathrm{~Hz}, 1 \mathrm{H}, \mathrm{C}\left(2^{\prime}\right)-\mathrm{OH}\right], 7.21-7.40[\mathrm{~m}, 15 \mathrm{H}$, trityl], $7.46\left[\mathrm{~d},{ }^{4} J=1.2 \mathrm{~Hz}, 1 \mathrm{H}, \mathrm{C}(6)-\mathrm{H}\right], 11.40$ [s, $\left.1 \mathrm{H}, \mathrm{N}(3)-\mathrm{H}\right] \mathrm{ppm}$. Exact mass (ESI-MS, $i \mathrm{PrOH} / \mathrm{H}_{2} \mathrm{O}$ ) calculated for $\mathrm{C}_{29} \mathrm{H}_{27} \mathrm{~N}_{5} \mathrm{O}_{5} \mathrm{Na}$ $[\mathrm{M}+\mathrm{Na}]^{+}$548.1910; found 548.1910. Trifluoromethanesulfonyl chloride $(1.0 \mathrm{~mL}, 9.36 \mathrm{mmol})$ was added to a cooled solution of 1 (3-azido-3-deoxy-5- $O$-trityl- $\beta$-D-ribofuranosyl)thymine $\quad(2.46 \mathrm{~g}$, $4.68 \mathrm{mmol})$ and DMAP $(2.30 \mathrm{~g}, 18.7 \mathrm{mmol})$ in dry $\mathrm{CH}_{2} \mathrm{Cl}_{2}$ $(50 \mathrm{~mL})$. After 2 hours the reaction was quenched with water $(15 \mathrm{~mL})$ and extracted. The organic layer was washed with a $7 \%$ $\mathrm{NaHCO}_{3}$ solution, dried with $\mathrm{MgSO}_{4}$, filtered, and the solvents evaporated to dryness to give a white semi-solid that was purified on a silica gel column $\left(\mathrm{CH}_{2} \mathrm{Cl}_{2} / \mathrm{MeOH}, 97 / 3\right)$ to give $1.91 \mathrm{~g}(81 \%)$ of 4. ${ }^{1} \mathrm{H}$ NMR $\left(300 \mathrm{MHz},\left[\mathrm{D}_{6}\right] \mathrm{DMSO}\right): \delta=1.79\left[\mathrm{~d},{ }^{4} \mathrm{~J}=0.9 \mathrm{~Hz}\right.$, $\left.3 \mathrm{H}, \mathrm{C}(5)-\mathrm{CH}_{3}\right], 2.77\left[\mathrm{dd},{ }^{3} \mathrm{~J}=7.6 \mathrm{~Hz}\right.$ and ${ }^{2} J_{5 \mathrm{a}}{ }^{\prime}, 5 \mathrm{~b},=-10.6 \mathrm{~Hz}, 1$ $\mathrm{H}, \mathrm{C}\left(5^{\prime}\right)-\mathrm{H}_{\mathrm{b}}$ ], $3.04\left[\mathrm{dd},{ }^{3} J=4.1 \mathrm{~Hz}, 1 \mathrm{H}, \mathrm{C}\left(5^{\prime}\right)-\mathrm{H}_{\mathrm{a}}\right], 4.38[\mathrm{~m}, 1 \mathrm{H}$, $\mathrm{C}\left(4^{\prime}\right)-\mathrm{H}$ ], $4.60\left[\mathrm{dd},{ }^{3} J=1.8 \mathrm{~Hz}\right.$ and $\left.{ }^{3} J=3.2 \mathrm{~Hz}, 1 \mathrm{H}, \mathrm{C}\left(3^{\prime}\right)-\mathrm{H}\right]$, $5.43\left[\mathrm{dd},{ }^{3} J=1.6 \mathrm{~Hz}\right.$ and $\left.{ }^{3} J=5.7 \mathrm{~Hz}, 1 \mathrm{H}, \mathrm{C}\left(2^{\prime}\right)-\mathrm{H}\right], 6.31\left[\mathrm{~d},{ }^{3} J=\right.$ $\left.5.7 \mathrm{~Hz}, 1 \mathrm{H}, \mathrm{C}\left(1^{\prime}\right)-\mathrm{H}\right], 7.20-7.28\left[\mathrm{~m}, 15 \mathrm{H}\right.$, trityl], $7.82\left[\mathrm{~d},{ }^{4} \mathrm{~J}=\right.$ $1.2 \mathrm{~Hz}, 1 \mathrm{H}, \mathrm{C}(6)-\mathrm{H}] \mathrm{ppm}$. Exact mass (ESI-MS, $i \mathrm{PrOH}: \mathrm{H}_{2} \mathrm{O}$ ) calculated for $\mathrm{C}_{29} \mathrm{H}_{26} \mathrm{~N}_{5} \mathrm{O}_{4}[\mathrm{M}+\mathrm{H}]^{+}$508.1984; found 508.1982.

1-(3-Azido-3-deoxy-5-O-trityl- $\beta$-D-arabinofuranosyl)thymine (5): A mixture of 4 (1.91 g, $3.76 \mathrm{mmol}), 1 \mathrm{~N} \mathrm{NaOH}(10 \mathrm{~mL})$, and $50 \%$ EtOH $(100 \mathrm{~mL})$ was stirred at room temperature for 4 hours. The solution was neutralised with HOAc:EtOH $(1: 1, \mathrm{v} / \mathrm{v})$ to $\mathrm{pH} \approx 7$. The resulting white solid was collected by filtration and washed with water. The solid was then dissolved in $\mathrm{CH}_{2} \mathrm{Cl}_{2}$, extracted with water, dried with $\mathrm{MgSO}_{4}$, filtered, and evaporated to dryness to produce $1.74 \mathrm{~g}(88.1 \%)$ of 5 as a white solid. ${ }^{1} \mathrm{H}$ NMR $(300 \mathrm{MHz}$, [D $]$ DMSO): $\delta=1.59\left[\mathrm{~d},{ }^{4} \mathrm{~J}=0.6 \mathrm{~Hz}, 3 \mathrm{H}, \mathrm{C}(5)-\mathrm{CH}_{3}\right], 3.28$ [dd, ${ }^{3} J=4.1 \mathrm{~Hz}$ and $\left.{ }^{2} J_{5 \mathrm{a}^{\prime}, 5 \mathrm{~b}^{\prime}}=-11.1 \mathrm{~Hz}, 2 \mathrm{H}, \mathrm{C}\left(5^{\prime}\right)-\mathrm{H}_{\mathrm{a}, \mathrm{b}}\right], 3.80[\mathrm{app}$ quinted, ${ }^{3} J=4.1 \mathrm{~Hz}$ and $\left.{ }^{3} J=8.2 \mathrm{~Hz}, 1 \mathrm{H}, \mathrm{C}\left(4^{\prime}\right)-\mathrm{H}\right], 4.15\left[\mathrm{t},{ }^{3} J=\right.$ $\left.7.5 \mathrm{~Hz}, 1 \mathrm{H}, \mathrm{C}\left(3^{\prime}\right)-\mathrm{H}\right], 4.34\left[\mathrm{~m}, 1 \mathrm{H}, \mathrm{C}\left(2^{\prime}\right)-\mathrm{H}\right], 6.07\left[\mathrm{~d},{ }^{3} J=6.2 \mathrm{~Hz}\right.$, $\left.1 \mathrm{H}, \mathrm{C}\left(1^{\prime}\right)-\mathrm{H}\right], 6.10\left[\mathrm{~d},{ }^{3} \mathrm{~J}=5.6 \mathrm{~Hz}, 1 \mathrm{H}, \mathrm{C}\left(2^{\prime}\right)-\mathrm{OH}\right], 7.24-7.40[\mathrm{~m}$, $15 \mathrm{H}$, trityl], 7.38 [d, $\left.{ }^{4} \mathrm{~J}=0.6 \mathrm{~Hz}, 1 \mathrm{H}, \mathrm{C}(6)-\mathrm{H}\right], 11.34$ [s, $1 \mathrm{H}, \mathrm{N}(3)-$ $\mathrm{H}]$ ppm. Exact mass (ESI-MS, $i$ PrOH: $\mathrm{H}_{2} \mathrm{O}$ ) calculated for $\mathrm{C}_{29} \mathrm{H}_{27} \mathrm{~N}_{5} \mathrm{O}_{5} \mathrm{Na}[\mathrm{M}+\mathrm{Na}]^{+}$548.1910; found 548.1906.

1-(3-Azido-3-deoxy- $\boldsymbol{\beta}$-D-arabinofuranosyl)thymine (6a): A suspension of compound $5(0.5 \mathrm{~g}, 0.95 \mathrm{mmol})$ in $80 \%$ HOAc $(10 \mathrm{~mL})$ was heated at $90{ }^{\circ} \mathrm{C}$ with stirring for $25 \mathrm{~min}$. The solution was evaporated in vacuo to give a residue that was chromatographed on a silica gel column $\left(\mathrm{CH}_{2} \mathrm{Cl}_{2} / \mathrm{MeOH}, 95: 5\right)$ to afford $0.2 \mathrm{~g}(78.6 \%)$ of 6a. ${ }^{1} \mathrm{H}$ NMR (300 MHz, $\left.\left[\mathrm{D}_{6}\right] \mathrm{DMSO}\right): \delta=1.74\left[\mathrm{~s},{ }^{4} \mathrm{~J}=1.2 \mathrm{~Hz}, 3\right.$ $\left.\mathrm{H}, \mathrm{C}(5)-\mathrm{CH}_{3}\right], 3.62\left[\mathrm{~m}, 3 \mathrm{H}, \mathrm{C}\left(4^{\prime}\right)-\mathrm{H}\right.$ and $\left.\mathrm{C}\left(5^{\prime}\right)-\mathrm{H}_{\mathrm{a}, \mathrm{b}}\right], 4.00\left[\mathrm{t},{ }^{3} J=\right.$ $\left.7.5 \mathrm{~Hz}, 1 \mathrm{H}, \mathrm{C}\left(3^{\prime}\right)-\mathrm{H}\right], 4.32\left[\mathrm{t},{ }^{3} J=6.6 \mathrm{~Hz}, 1 \mathrm{H}, \mathrm{C}\left(2^{\prime}\right)-\mathrm{H}\right], 5.29[\mathrm{br}$. s, $\left.1 \mathrm{H}, \mathrm{C}\left(5^{\prime}\right)-\mathrm{OH}\right], 5.99\left[\mathrm{~d},{ }^{3} J=6.2 \mathrm{~Hz}, 1 \mathrm{H}, \mathrm{C}\left(1^{\prime}\right)-\mathrm{H}\right], 6.07$ [d, $\left.{ }^{3} J=0.6 \mathrm{~Hz}, 1 \mathrm{H}, \mathrm{C}\left(2^{\prime}\right)-\mathrm{OH}\right], 7.58\left[\mathrm{~d},{ }^{4} J=1.2 \mathrm{~Hz}, 1 \mathrm{H}, \mathrm{C}(6)-\mathrm{H}\right]$, 11.27 [s, $1 \mathrm{H}, \mathrm{N}(3)-\mathrm{H}] \mathrm{ppm} .{ }^{13} \mathrm{C} \mathrm{NMR}\left(75 \mathrm{MHz},\left[\mathrm{D}_{6}\right] \mathrm{DMSO}\right): \delta=$ $12.84,60.20,64.84,74.80,80.26,83.78,108.70,138.29,151.14$, $164.503 \mathrm{ppm}$. Exact mass (ESI-MS, $i \operatorname{PrOH}: \mathrm{H}_{2} \mathrm{O}$ ) calculated for $\mathrm{C}_{10} \mathrm{H}_{13} \mathrm{~N}_{5} \mathrm{O}_{5} \mathrm{Na}[\mathrm{M}+\mathrm{Na}]^{+}$306.0814; found 306.0810.

1-(3-Azido-2-chloro-2,3-dideoxy- $\beta$-D-ribofuranosyl)thymine (7a): (310 mg, $0.61 \mathrm{mmol}$ ) of $\mathbf{4}$ was transferred into a sealable glass vial and $4 \mathrm{M} \mathrm{HCl}$ in dioxane $(20 \mathrm{~mL})$ was added. The vial was firmly sealed and temperature was raised to $75-80^{\circ} \mathrm{C}$ for 24 hours. After cooling to room temperature the reaction mixture was evaporated in vacuo and purified on a silica gel column $\mathrm{CH}_{2} \mathrm{Cl}_{2} / \mathrm{MeOH}$ (98:2) to give $170 \mathrm{mg}(92 \%)$ of $7 \mathbf{a} .{ }^{1} \mathrm{H}$ NMR $\left(300 \mathrm{MHz},\left[\mathrm{D}_{6}\right] \mathrm{DMSO}\right)$ : $\delta=1.75\left[\mathrm{~d},{ }^{4} \mathrm{~J}=1.2 \mathrm{~Hz}, 3 \mathrm{H}, \mathrm{C}(5)-\mathrm{CH}_{3}\right], 3.61\left[\mathrm{ddd},{ }^{3} \mathrm{~J}=3.0 \mathrm{~Hz}\right.$ and ${ }^{3} J=5.0 \mathrm{~Hz}$ and $\left.{ }^{2} J_{5 \mathrm{a}^{\prime}, 5 \mathrm{~b}^{\prime}}=-12.6 \mathrm{~Hz}, 1 \mathrm{H}, \mathrm{C}\left(5^{\prime}\right)-\mathrm{H}_{\mathrm{b}}\right], 3.75$ $\left[\mathrm{ddd},{ }^{3} J=3.1 \mathrm{~Hz}\right.$ and ${ }^{3} J=5.3 \mathrm{~Hz}, 1 \mathrm{H}, \mathrm{C}\left(5^{\prime}\right)-\mathrm{H}_{\mathrm{a}}$ ], 3.99 [app quinted, ${ }^{3} J=2.9 \mathrm{~Hz}$ and ${ }^{3} J=3.13 \mathrm{~Hz}$ and ${ }^{3} J=6.0 \mathrm{~Hz}, 1 \mathrm{H}$, $\left.\mathrm{C}\left(4^{\prime}\right)-\mathrm{H}\right], 4.57\left[\mathrm{t},{ }^{3} \mathrm{~J}=5.7 \mathrm{~Hz}, 1 \mathrm{H}, \mathrm{C}\left(3^{\prime}\right)-\mathrm{H}\right], 4.92\left[\mathrm{t},{ }^{3} \mathrm{~J}=5.1 \mathrm{~Hz}\right.$, $\left.1 \mathrm{H}, \mathrm{C}\left(2^{\prime}\right)-\mathrm{H}\right], 5.47\left[\mathrm{t},{ }^{3} \mathrm{~J}=4.7 \mathrm{~Hz}, 1 \mathrm{H}, \mathrm{C}\left(5^{\prime}\right)-\mathrm{OH}\right], 5.93\left[\mathrm{~d},{ }^{3} \mathrm{~J}=\right.$ $\left.4.7 \mathrm{~Hz}, 1 \mathrm{H}, \mathrm{C}\left(1^{\prime}\right)-\mathrm{H}\right], 7.80\left[\mathrm{~d},{ }^{4} J=1.2 \mathrm{~Hz}, 1 \mathrm{H}, \mathrm{C}(6)-\mathrm{H}\right], 11.46$ [s, $1 \mathrm{H}, \mathrm{N}(3)-\mathrm{H}] \mathrm{ppm} .{ }^{13} \mathrm{C} \mathrm{NMR}\left(75 \mathrm{MHz},\left[\mathrm{D}_{6}\right] \mathrm{DMSO}\right): \delta=12.92$, $60.37,61.10, \quad 61.90, \quad 83.12, \quad 89.02, \quad 110.23, \quad 135.89, \quad 151.17$, $164.29 \mathrm{ppm}$. Exact mass (ESI-MS, $i \mathrm{PrOH}: \mathrm{H}_{2} \mathrm{O}$ ) calculated for $\mathrm{C}_{10} \mathrm{H}_{13} \mathrm{Cl}_{1} \mathrm{~N}_{5} \mathrm{O}_{4}[\mathrm{M}+\mathrm{H}]^{+}$302.0655; found 302.0658.

1-(3-Azido-2,3-dideoxy-2-fluoro- $\beta$-D-ribofuranosyl)thymine (8a): To a solution of $5(1.59 \mathrm{~g}, 3.0 \mathrm{mmol})$ in toluene $(30 \mathrm{~mL})$ and pyridine (3 mL), DAST $(1.5 \mathrm{~mL}, 11.3 \mathrm{mmol})$ was added and stirred at room temperature for $2 \mathrm{~h}$ before heating the reaction mixture to $50{ }^{\circ} \mathrm{C}$. After 5 hours EtOAc $(170 \mathrm{~mL})$ was added and the organic layer washed successively with $7 \% \mathrm{NaHCO}_{3}(200 \mathrm{~mL})$ and $\mathrm{H}_{2} \mathrm{O}$ $(200 \mathrm{~mL})$, dried with $\mathrm{MgSO}_{4}$, filtered, and concentrated in vacuo. The residue was purified on a silica gel column prepared in $\mathrm{CHCl}_{3}$ and eluted with $\mathrm{CHCl}_{3} / \mathrm{MeOH}, 99: 1$ to give $1.45 \mathrm{~g}(90 \%)$ of 1-(3azido-2,3-dideoxy-2-fluoro-5- $O$-trityl- $\beta$-D-ribofuranosyl)thymine: 
${ }^{1} \mathrm{H}$ NMR $\left(300 \mathrm{MHz},\left[\mathrm{D}_{6}\right] \mathrm{DMSO}\right): \delta=1.52\left[\mathrm{~d},{ }^{4} \mathrm{~J}=0.9 \mathrm{~Hz}, 3 \mathrm{H}\right.$, $\left.\mathrm{C}(5)-\mathrm{CH}_{3}\right], 3.24\left[\mathrm{dd},{ }^{3} J=4.1 \mathrm{~Hz}\right.$ and ${ }^{2} J_{5 \mathrm{a}}{ }^{\prime}, 5 \mathrm{~b},=-11.1 \mathrm{~Hz}, 1 \mathrm{H}$, $\mathrm{C}\left(5^{\prime}\right)-\mathrm{H}_{\mathrm{b}}$ ], 3.35 [dd, ${ }^{3} \mathrm{~J}=2.4 \mathrm{~Hz}, 1 \mathrm{H}, \mathrm{C}\left(5^{\prime}\right)-5_{\mathrm{a}}$ ], 4.12 [m, $1 \mathrm{H}, \mathrm{C}\left(4^{\prime}\right)-$ $\mathrm{H}], 4.56\left[\mathrm{ddd},{ }^{3} J=4.7 \mathrm{~Hz}\right.$ and ${ }^{3} J=9.5 \mathrm{~Hz}$ and ${ }^{3} J_{3^{\prime}, \mathrm{F}}=24.5 \mathrm{~Hz}$, $1 \mathrm{H}, \mathrm{C}\left(3^{\prime}\right)-\mathrm{H}$ ], $5.53\left[\mathrm{dd},{ }^{3} J=4.8 \mathrm{~Hz}\right.$ and ${ }^{2} J_{2^{\prime}, \mathrm{F}}=52.9 \mathrm{~Hz}, 1 \mathrm{H}$, $\left.\mathrm{C}\left(2^{\prime}\right)-\mathrm{H}\right], 5.91\left[\mathrm{dd},{ }^{3} J=1.1 \mathrm{~Hz}\right.$ and ${ }^{3} J_{1^{\prime}, \mathrm{F}}=21.6 \mathrm{~Hz}, 1 \mathrm{H}, \mathrm{C}\left(1^{\prime}\right)$ $\mathrm{H}], 7.24-7.40\left[\mathrm{~m}, 15 \mathrm{H}\right.$, trityl], $7.51\left[\mathrm{~d},{ }^{4} \mathrm{~J}=1.2 \mathrm{~Hz}, 1 \mathrm{H}, \mathrm{C}(6)-\mathrm{H}\right]$, 11.51 [br. s, $1 \mathrm{H}, \mathrm{N}(3)-\mathrm{H}$ ] ppm. Exact mass (ESI-MS, $i \mathrm{PrOH}: \mathrm{H}_{2} \mathrm{O}$ ) calculated for $\mathrm{C}_{29} \mathrm{H}_{26} \mathrm{~F}_{1} \mathrm{~N}_{5} \mathrm{O}_{4} \mathrm{Na}[\mathrm{M}+\mathrm{Na}]^{+}$550.1866; found 550.1862. 1-(3-Azido-2,3-dideoxy-2-fluoro-5- $O$-trityl- $\beta$-D-ribofuranosyl)thymine $(1.45 \mathrm{~g}, 2.75 \mathrm{mmol})$ was detritylated to $0.52 \mathrm{~g}$ (64 $\%$ ) of 8 a (see procedure $6 \mathrm{a}) .{ }^{1} \mathrm{H}$ NMR $\left(300 \mathrm{MHz},\left[\mathrm{D}_{6}\right] \mathrm{DMSO}\right): \delta=$ $1.74\left[\mathrm{~d},{ }^{4} J=1.2 \mathrm{~Hz}, 3 \mathrm{H}, \mathrm{C}(5)-\mathrm{CH}_{3}\right], 3.60\left[\mathrm{dd},{ }^{3} J=2.9 \mathrm{~Hz}\right.$ and $\left.{ }^{2} J_{5 \mathrm{a}^{\prime}, 5 \mathrm{~b}},=-12.6 \mathrm{~Hz}, 1 \mathrm{H}, \mathrm{C}\left(5^{\prime}\right)-\mathrm{H}_{\mathrm{b}}\right], 3.79\left[\mathrm{dd},{ }^{3} \mathrm{~J}=2.6 \mathrm{~Hz}, 1 \mathrm{H}\right.$, $\mathrm{C}\left(5^{\prime}\right)-\mathrm{H}_{\mathrm{a}}$ ] $3.98\left[\mathrm{dt},{ }^{3} J=2.6 \mathrm{~Hz}\right.$ and $\left.{ }^{3} J=8.8 \mathrm{~Hz}, 1 \mathrm{H}, \mathrm{C}\left(4^{\prime}\right)-\mathrm{H}\right]$, 4.30 [ddd, ${ }^{3} J=4.6 \mathrm{~Hz}$ and ${ }^{3} J=8.9 \mathrm{~Hz}$ and ${ }^{3} J_{3^{\prime}, F}=23.5 \mathrm{~Hz}, 1 \mathrm{H}$, $\mathrm{C}\left(3^{\prime}\right)-\mathrm{H}$ ], $5.42\left[\mathrm{ddd},{ }^{3} J=1.5 \mathrm{~Hz}\right.$ and ${ }^{3} J=4.5 \mathrm{~Hz}$ and ${ }^{2} J_{2^{\prime}, F}=$ $52.9 \mathrm{~Hz}, 1 \mathrm{H}, \mathrm{C}\left(2^{\prime}\right)-\mathrm{H}$ ], 5.43 [br. s, $1 \mathrm{H}, \mathrm{C}\left(5^{\prime}\right)-\mathrm{OH}$ ], 5.90 [dd, ${ }^{3} \mathrm{~J}=$ $1.6 \mathrm{~Hz}$ and $\left.J_{I^{\prime}, F}=19.2 \mathrm{~Hz}, 1 \mathrm{H}, \mathrm{C}\left(1^{\prime}\right)-\mathrm{H}\right], 7.74\left[\mathrm{~d},{ }^{4} J=1.2 \mathrm{~Hz}, 1\right.$ $\mathrm{H}, \mathrm{C}(6)-\mathrm{H}$ ], 11.44 [br. s, $1 \mathrm{H}, \mathrm{N}(3)-\mathrm{H}$ ] ppm. ${ }^{13} \mathrm{C} \mathrm{NMR}(75 \mathrm{MHz}$, [D $\mathrm{D}_{6}$ DMSO $): \delta=12.76,58.67(J=15.3 \mathrm{~Hz}), 59.76,81.65,88.38$ $(J=34.8 \mathrm{~Hz}), 94.68(J=186.3 \mathrm{~Hz}), 110.10,136.89,150.84$, $164.51 \mathrm{ppm}$. Exact mass (ESI-MS, $i \mathrm{PrOH}: \mathrm{H}_{2} \mathrm{O}$ ) calculated for $\mathrm{C}_{10} \mathrm{H}_{12} \mathrm{~F}_{1} \mathrm{~N}_{5} \mathrm{O}_{4} \mathrm{Na}[\mathrm{M}+\mathrm{Na}]^{+}$308.0771; found 308.0759.

General Procedure for the Synthesis of the $3^{\prime}$-Amine-Modified Nucleosides 3b, 6b-8b from the $3^{\prime}$-Azide-Modified Nucleosides 3a, 6a8a: The $3^{\prime}$-azido-modified nucleoside $(1 \mathrm{mmol})$ was dissolved in dry pyridine $(8 \mathrm{~mL})$ and $\mathrm{PhP}_{3}(1.6 \mathrm{mmol})$ was added to the solution. After stirring at room temperature for $1.5 \mathrm{~h}$, concentrated $\mathrm{NH}_{4} \mathrm{OH}$ $(3 \mathrm{~mL})$ was added. The reaction mixture was stirred for another $2 \mathrm{~h}$, evaporated to dryness and purified by silica gel chromatography $\left(\mathrm{CH}_{2} \mathrm{Cl}_{2} / \mathrm{MeOH}\right)$.

1-(3-Amino-3-deoxy- $\beta$-D-ribofuranosyl)thymine $\quad$ (3b): $\quad$ (500 mg, $1.77 \mathrm{mmol})$ of $\mathbf{3 a}$ yielded $320 \mathrm{mg}(71 \%)$ of $\mathbf{3 b}$ as a white solid. ${ }^{1} \mathrm{H}$ NMR $\left(300 \mathrm{MHz},\left[\mathrm{D}_{6}\right] \mathrm{DMSO}\right): \delta=1.75\left[\mathrm{~s}, 3 \mathrm{H}, \mathrm{C}(5)-\mathrm{CH}_{3}\right], 3.21$ $\left[\mathrm{dd},{ }^{3} J=5.4 \mathrm{~Hz}\right.$ and $\left.{ }^{3} J=7.7 \mathrm{~Hz}, 1 \mathrm{H}, \mathrm{C}\left(3^{\prime}\right)-\mathrm{H}\right], 3.60[\mathrm{~m}, 2 \mathrm{H}$, $\mathrm{C}\left(4^{\prime}\right)-\mathrm{H}$ and $\mathrm{C}\left(5^{\prime}\right)-\mathrm{H}_{\mathrm{b}}$ ], 3.74 [app d, ${ }^{2} J_{5 \mathrm{a}^{\prime}, 5 \mathrm{~b}^{\prime}}=-11.2 \mathrm{~Hz}, 1 \mathrm{H}$, $\mathrm{C}\left(5^{\prime}\right)-\mathrm{H}_{\mathrm{a}}$ ], $3.86\left[\mathrm{dd},{ }^{3} \mathrm{~J}=2.4 \mathrm{~Hz}\right.$ and $\left.{ }^{3} \mathrm{~J}=5.3 \mathrm{~Hz}, 1 \mathrm{H}, \mathrm{C}\left(2^{\prime}\right)-\mathrm{H}\right]$, 5.11 [br. s, $1 \mathrm{H}, \mathrm{C}\left(5^{\prime}\right)-\mathrm{OH}$ ], $5.69\left[\mathrm{~d},{ }^{3} J=2.4 \mathrm{~Hz}, 1 \mathrm{H}, \mathrm{C}\left(1^{\prime}\right)-\mathrm{H}\right.$ ], 7.61 [s, $1 \mathrm{H}, \mathrm{C}(6)-\mathrm{H}]$ ppm. ${ }^{13} \mathrm{C}$ NMR (75 MHz, [D $]$ DMSO): $\delta=$ $12.85,52.42,60.74,75.39,85.55,90.12,109.29,137.16,151.13$, $164.48 \mathrm{ppm}$. Exact mass (ESI-MS, $i \mathrm{PrOH}: \mathrm{H}_{2} \mathrm{O}$ ) calculated for $\mathrm{C}_{10} \mathrm{H}_{16} \mathrm{~N}_{3} \mathrm{O}_{5} \mathrm{Na}[\mathrm{M}+\mathrm{H}]^{+}$258.1089; found 258.1095.

1-(3-Amino-3-deoxy- $\beta$-D-arabinofuranosyl)thymine (6b): $\quad(120 \mathrm{mg}$, $0.42 \mathrm{mmol})$ of $\mathbf{6 a}$ yielded $60 \mathrm{mg}(54 \%)$ of $\mathbf{6 b}$ as a white solid. ${ }^{1} \mathrm{H}$ NMR (300 MHz, [D 6 DMSO): $\delta=1.73\left[\mathrm{~d},{ }^{4} J=1.2 \mathrm{~Hz}, 3 \mathrm{H}, \mathrm{C}(5)-\right.$ $\left.\mathrm{CH}_{3}\right), 3.05\left[\mathrm{t},{ }^{3} \mathrm{~J}=6.2 \mathrm{~Hz}, 1 \mathrm{H}, \mathrm{C}\left(3^{\prime}\right)-\mathrm{H}\right], 3.50\left[\mathrm{~m}, 1 \mathrm{H}, \mathrm{C}\left(4^{\prime}\right)-\mathrm{H}\right]$, 3.61 [app t, ${ }^{2} J_{5 \mathrm{a}^{\prime}, 5 \mathrm{~b}},=15.8 \mathrm{~Hz}, 2 \mathrm{H}, \mathrm{C}\left(5^{\prime}\right)-\mathrm{H}_{\mathrm{a}, \mathrm{b}}$ ], 3.90 [br. q, ${ }^{3} J=$ $5.0 \mathrm{~Hz}$ and $\left.{ }^{3} J=9.7 \mathrm{~Hz}, 1 \mathrm{H}, \mathrm{C}\left(2^{\prime}\right)-\mathrm{H}\right], 5.04\left[\mathrm{~s}, 1 \mathrm{H}, \mathrm{C}\left(5^{\prime}\right)-\mathrm{OH}\right]$, $5.42\left[\mathrm{~d},{ }^{3} J=4.4 \mathrm{~Hz}, 1 \mathrm{H}, \mathrm{C}\left(2^{\prime}\right)-\mathrm{OH}\right], 5.98\left[\mathrm{~d},{ }^{3} J=5.6 \mathrm{~Hz}, 1 \mathrm{H}\right.$, $\mathrm{C}\left(1^{\prime}\right)-\mathrm{H}$ ], $7.60\left[\mathrm{~d},{ }^{4} J=1.2 \mathrm{~Hz}, 1 \mathrm{H}, \mathrm{C}(6)-\mathrm{H}\right] \mathrm{ppm} .{ }^{13} \mathrm{C} \mathrm{NMR}$ (75 MHz, [D 6 DMSO): $\delta=12.88,57.83,60.99,77.41,84.54,84.66$, $107.97,138.82,151.15,164.59 \mathrm{ppm}$. Exact mass (ESI-MS, $i \mathrm{P}-$ rOH: $\mathrm{H}_{2} \mathrm{O}$ ) calculated for $\mathrm{C}_{10} \mathrm{H}_{16} \mathrm{~N}_{3} \mathrm{O}_{5}[\mathrm{M}+\mathrm{H}]^{+} 258.1089$; found 258.1084

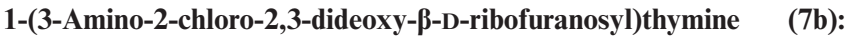
$(90 \mathrm{mg}, 0.30 \mathrm{mmol})$ of $7 \mathbf{a}$ yielded $24 \mathrm{mg}(30 \%)$ of $7 \mathbf{b}$ as a white solid. ${ }^{1} \mathrm{H}$ NMR $\left(300 \mathrm{MHz},\left[\mathrm{D}_{6}\right] \mathrm{DMSO}\right): \delta=1.73\left[\mathrm{~d},{ }^{4} J=0.9 \mathrm{~Hz}\right.$, $3 \mathrm{H}, \mathrm{C}(5)-\mathrm{CH}_{3}$ ], 1.85 [br. s, $2 \mathrm{H}, \mathrm{C}\left(3^{\prime}\right)-\mathrm{NH}_{2}$ ], $3.50\left[\mathrm{dd},{ }^{3} J=5.3 \mathrm{~Hz}\right.$ and ${ }^{3} J=7.9 \mathrm{~Hz}, 1 \mathrm{H}, \mathrm{C}\left(3^{\prime}\right)-\mathrm{H}$ ], $3.62\left[\mathrm{ddd},{ }^{3} J=2.6 \mathrm{~Hz}\right.$ and ${ }^{3} J=$ $4.7 \mathrm{~Hz}$ and $\left.{ }^{2} J_{5 \mathrm{a}^{\prime}, 5 \mathrm{~b}^{\prime}}=-12.2 \mathrm{~Hz}, 1 \mathrm{H}, \mathrm{C}\left(5^{\prime}\right)-\mathrm{H}_{\mathrm{b}}\right], 3.75\left[\mathrm{~m}, 2 \mathrm{H}, \mathrm{C}\left(4^{\prime}\right)\right.$ and $\mathrm{C}\left(5^{\prime}\right)-\mathrm{H}_{\mathrm{a}}$ ], $4.53\left[\mathrm{dd},{ }^{3} J=2.4 \mathrm{~Hz}\right.$ and ${ }^{3} J=5.3 \mathrm{~Hz}, 1 \mathrm{H}, \mathrm{C}\left(2^{\prime}\right)-$ $\mathrm{H}], 5.26\left[\mathrm{t},{ }^{3} \mathrm{~J}=5.0 \mathrm{~Hz}, 1 \mathrm{H}, \mathrm{C}\left(5^{\prime}\right)-\mathrm{OH}\right], 5.94\left[\mathrm{~d},{ }^{3} \mathrm{~J}=2.6 \mathrm{~Hz}, 1\right.$ $\left.\mathrm{H}, \mathrm{c}\left(1^{\prime}\right)-\mathrm{H}\right], 7.99\left[\mathrm{~d},{ }^{4} J=1.5 \mathrm{~Hz}, 1 \mathrm{H}, \mathrm{C}(6)-\mathrm{H}\right], 11.35$ [s, $1 \mathrm{H}, \mathrm{n}(3)-$ $\mathrm{H}] \mathrm{ppm} .{ }^{13} \mathrm{C}$ NMR $\left(75 \mathrm{MHz},\left[\mathrm{D}_{6}\right] \mathrm{DMSO}\right): \delta=12.91,52.06,59.97$, 84.69, 89.64, 91.10, 109.64, 136.22, 151.09, $164.42 \mathrm{ppm}$. Exact mass (ESI-MS, $i$ PrOH: $\mathrm{H}_{2} \mathrm{O}$ ) calculated for $\mathrm{C}_{10} \mathrm{H}_{15} \mathrm{Cl}_{1} \mathrm{~N}_{3} \mathrm{O}_{4}[\mathrm{M}+\mathrm{H}]^{+}$ 276.0750; found 276.0765 .

1-(3-Amino-2,3-dideoxy-2-fluoro- $\beta$-D-ribofuranosyl)thymine (8b): $120 \mathrm{mg}, 0.42 \mathrm{mmol}$ of $\mathbf{8 a}$ yielded $60 \mathrm{mg}(55 \%)$ of $\mathbf{8 b}$ as a white solid. ${ }^{1} \mathrm{H}$ NMR (300 MHz, [D 6 DMSO): $\delta=1.72\left[\mathrm{~d},{ }^{4} J=1.2 \mathrm{~Hz}\right.$, $3 \mathrm{H}, \mathrm{C}(5)-\mathrm{CH}_{3}$ ], $3.32\left[\mathrm{ddd},{ }^{3} J=4.3 \mathrm{~Hz}\right.$ and ${ }^{3} J=9.7 \mathrm{~Hz}$ and $\left.{ }^{3} J_{3^{\prime}, F}=28.6 \mathrm{~Hz}, 1 \mathrm{H}, \mathrm{C}\left(3^{\prime}\right)-\mathrm{H}\right], 3.61\left[\mathrm{~m}, 2 \mathrm{H}, \mathrm{C}\left(4^{\prime}\right)-\mathrm{H}\right.$ and $\mathrm{C}\left(5^{\prime}\right)-$ $\mathrm{H}_{\mathrm{b}}$ ], $3.78\left[\mathrm{dd},{ }^{3} J=1.76 \mathrm{~Hz}\right.$ and ${ }^{2} J_{5 \mathrm{a}^{\prime}, 5 \mathrm{~b}^{\prime}}=-12.3 \mathrm{~Hz}, 1 \mathrm{H}, \mathrm{C}\left(5^{\prime}\right)-$ $\mathrm{H}_{\mathrm{a}}$ ], $4.87\left[\mathrm{dd},{ }^{3} J=4.1 \mathrm{~Hz}\right.$ and $\left.{ }^{2} J_{2^{\prime}, F}=53.1 \mathrm{~Hz}, 1 \mathrm{H}, \mathrm{C}\left(2^{\prime}\right)-\mathrm{H}\right], 5.19$ [br. s, $1 \mathrm{H}, \mathrm{C}\left(5^{\prime}\right)-\mathrm{OH}$ ], 5.83 [d, $\left.{ }^{3} J_{1^{\prime}, F}=18.2 \mathrm{~Hz}, 1 \mathrm{H}, \mathrm{C}\left(1^{\prime}\right)-\mathrm{H}\right], 7.86$ $\left[\mathrm{d},{ }^{4} \mathrm{~J}=1.2 \mathrm{~Hz}, 1 \mathrm{H}, \mathrm{C}(6)-\mathrm{H}\right]$ ppm. ${ }^{13} \mathrm{C} \mathrm{NMR}(75 \mathrm{MHz}$, [D $\mathrm{D}_{6}$ DMSO): $\delta=12.82,51.73(\mathrm{~J}=18.1 \mathrm{~Hz}), 59.54,84.83,88.30$ $(J=35.7 \mathrm{~Hz}), 96.72(J=180.5 \mathrm{~Hz}), 109.54,136.80,150.79$, $164.52 \mathrm{ppm}$. Exact mass (ESI-MS, $i \mathrm{PrOH}: \mathrm{H}_{2} \mathrm{O}$ ) calculated for $\mathrm{C}_{10} \mathrm{H}_{15} \mathrm{~F}_{1} \mathrm{~N}_{3} \mathrm{O}_{4}[\mathrm{M}+\mathrm{H}]^{+}$260.1046; found 260.1053.

TMPK Assay: Activity was determined by using the coupled spectrophotometric assay at $334 \mathrm{~nm}(0.5 \mathrm{~mL}$ final volume $)$ in an Eppendorf ECOM 6122 photometer. ${ }^{[31]}$ One unit of enzyme activity corresponds to $1 \mu \mathrm{mol}$ of the product formed in 1 minute at $30{ }^{\circ} \mathrm{C}$ and $\mathrm{pH}$ 7.4. The concentration of ATP and dTMP were kept constant at $0.5 \mathrm{~mm}$ and $0.05 \mathrm{~mm}$, respectively, whereas the concentrations of analogues varied between $0.01 \mathrm{~mm}$ and $4 \mathrm{~mm}$. The reaction medium $(0.5 \mathrm{~mL}$ final volume $)$ contained $50 \mathrm{~mm}$ of tris(hydroxymethyl)aminomethane $\mathrm{HCl}(\mathrm{pH} 7.4), 50 \mathrm{~mm}$ of $\mathrm{KCl}$, $2 \mathrm{~mm}$ of $\mathrm{MgCl}_{2}, 0.2 \mathrm{~mm}$ of $\mathrm{NADH}, 1 \mathrm{~mm}$ ofphosphoenol pyruvate, and 2 units each of lactate dehydrogenase, pyruvate kinase, and nucleoside diphosphate kinase.

Pseudorotational Analysis: NMR samples were prepared with $3 \mathrm{mg}$ of compounds $7 \mathbf{a}-\mathbf{b}$ and $\mathbf{8 a}-\mathbf{b}$, dissolved in $250 \mu \mathrm{L}$ of $\mathrm{D}_{2} \mathrm{O}$ and the $\mathrm{pD}$ was adjusted to 7.4 (same conditions used during the TMPKmt assay). High resolution $1 \mathrm{D}{ }^{1} \mathrm{H}$ spectra were recorded on a Varian $500 \mathrm{MHz}$ Unity spectrometer, operating at $499.505 \mathrm{MHz}$. Quadrature detection was achieved by States-Haberkorn hypercomplex mode. ${ }^{[32]}$ Coupling constants were examined for all four analogues between $278 \mathrm{~K}$ and $333 \mathrm{~K}$. The ring conformations of the synthetic nucleosides were analysed with the program PSEUROT $6.2^{[26]}$ (DOS version) running on a Pentium II $350-\mathrm{MHz}$ personal computer. This version includes an improved generalized Karplus equation for the iterative generation of coupling constants based on the experimental data as described by Donders et al. ${ }^{[33]}$ The standard values for substituent electronegativities (supplied with the 6.2 version $)^{[26]}$ were used in the iterations. For the azide function the $\lambda$ value of 0.85 was used. ${ }^{[22 \mathrm{~b}]}$ For the calculations an iterative strategy was adopted in which the pseudorotational parameters, obtained for each set of coupling constants, were calculated repeatedly after minor changes were systematically made in the starting parameters. If there was reason to believe that a specific derivative preferred a particular ring puckering, the minor conformer was held fixed during the iteration. The quality of the data was measured in the RMS deviation of the calculated and experimental coupling constants. In general, the RMS deviation (between the experimental and calculated coupling constants) was less than 0.2 , indicating the parameterisation of the program was well suited to the input data (see Table 3).

$\mathbf{N} \rightleftarrows \mathbf{S}$ Energy Calculations: For each compound, the mole fraction of $\mathrm{S}\left(X_{\mathrm{s}}\right)$ at each temperature interval (see Table 2.), obtained from 
the PSEUROT ${ }^{[26]}$ analysis, was used to make the van't Hoff plots (not shown here). The slopes and intercepts of these van't Hoff plots were subsequently used to calculate the $\Delta H^{\circ}$ and $\Delta S^{\circ}$ of the $\mathrm{N} \rightleftarrows \mathrm{S}$ two-state pseudorotational equilibrium of compounds $7 \mathbf{a}-\mathbf{b}$ and $\mathbf{8 a}-\mathbf{b}$ (see Table 4). The correlation coefficients $\left(R^{2}\right)$ of the van't Hoff plots are: 0.96 (7a), 0.93 (7b), $0.81(\mathbf{8 a})$, and $0.92(\mathbf{8 b})$. $\Delta G^{\circ}$ and $X_{\mathrm{S}}$ were calculated at $303 \mathrm{~K}$ by using the determined $\Delta H^{\circ}$ and $\Delta S^{\circ}$ values (see Table 4 ).

\section{Acknowledgments}

Philippe Van Rompaey is a recipient of an IWT-scolarship ( ${ }^{\circ}$ 3028). Koen Nauwelaerts and Veerle Vanheusden are indepted to the "Fonds voor Wetenschappelijk Onderzoek (FWO) - Vlaanderen" for a position as aspirant and the financial support. Hélène Munier-Lehmann (position at the Institut National de la Santé et de la Recherche Médicale) was supported by grants from the Institut Pasteur and the Ministère de la Recherché (ACI Molécules et Cibles Thérapeutiques).

[1] E. Stokstad, Science 2000, 287, 2391.

[2] M. D. Raviglione, D. E. Snider Jr., A. Kochi, JAMA 1995, 273, 220-226.

[3] http://www.who.int/mediacentre/factsheets/who104/en/ index.html (WHO Global tuberculosis programme - Tuberculosis Fact Sheet, 2002).

${ }^{[4]}$ T. Nguyen, B. Stout, OutLook 1999, 17, 1-8.

[5] http://www.who.int/gtb/dots/index.htm (WHO Global tuberculosis programme - An expanded DOTS framework for effective tuberculosis control, 2002).

[6] S. W. Dooley, W. R. Jarvis, W. J. Martone, D. E. Snyder Jr, Ann. Intern. Med. 1992, 117, 257-259.

[7] H. Munier-Lehmann, A. Chaffotte, S. Pochet, G. Labesse, Protein Science 2001, 10, 1195-1205.

${ }^{[8]}$ L. de la Sierra, H. Munier-Lehmann, A. M. Gilles, O. Bârzu, M. Delarue, J. Mol. Biol. 2001, 311, 87-100.

[9] S. Pochet, L. Dugué, D. Douguet, G. Labesse, H. MunierLehmann, ChemBio Chem 2002, 3, 108-110.

[10] [10a] V. Vanheusden, H. Munier-Lehmann, S. Pochet, P. Herdewijn, S. Van Calenbergh, Bioorg. Med. Chem. Lett. 2002, 12, 2695-2698. [10b] P. Van Rompaey, V. Vanheusden, S. Pochet, H. Munier-Lehmann, M. Froeyen, P. Herdewijn, S. Van Calenbergh, Collection Symposium Series 2002, 5, 393-395.

${ }^{[11]}$ V. Vanheusden, H. Munier-Lehmann, M. Froeyen, L. Dugué, A. Heyerick, D. De Keukeleire, S. Pochet, P. Herdewijn, S. Van Calenbergh, J. Med. Chem., manuscript submitted.

${ }^{[12]}{ }^{[12 a]}$ A. V. Azhayev, A. M. Ozols, A. S. Bushnev, N. B. Dyatkina, S. V. Kochetkova, L. S. Victorova, M. K. Kukhanova, A. A. Krayevsky, B. P. Gottikh, Nucleic Acids Res. 1979, 6, 625-643. ${ }^{[12 b]}$ A. M. Ozols, A. V. Azhayev, N. B. Dyatkina, A. A. Krayevski, Synthesis 1980, 7, 557-558.

${ }^{[13]}$ H. Vorbrüggen, K. Krolikiewicz, B. Bennua, Chem. Ber. 1981, $114,1234-1255$.

${ }^{[14]}$ S. M. Gryaznov, H. Winter, Nucleic Acids Res. 1998, 26, 4160-4167.
${ }^{[15]}$ Y. Aoyama, T. Sekine, Y. Iwamoto, E. Kawashima, Y. Ishido, Nucleosides Nucleotides 1996, 15, 733-738.

${ }^{[16]}$ T.-S. Lin, J.-H. Yang, M.-C. Liu, Z.-Y. Shen, Y.-C. Cheng, W. H. Prusoff, G. I. Birnbaum, J. Giziewicz, I. Ghazzouli, V. Brankovan, J.-S. Feng, G.-D. Hsiung, J. Med. Chem. 1991, 34, $693-701$.

[17] [17a] A. V. Papchikhin, P. P. Purygin, A. V. Azhaev, A. A. Kraevskii, T. V. Kutateladze, Z. G. Chidzhavadze, R. Sh. Bibilashvilli, S. Bioorg. Khim. 1985, 11, 1367-1379. [17b] T. R. Webb, H. Mitsuya, S. Broder, J. Med. Chem. 1988, 31, 1475-1479.

${ }^{[18]}$ J. F. Codington, I. L. Doerr, J. J. Fox, J. Org. Chem. 1964, $29,558-564$.

${ }^{[19]}$ W. J. Middleton, J. Org. Chem. 1975, 40, 574-578.

[20] [20a] P. Herdewijn, A. Van Aerschot, Bull. Soc. Chim. Belg 1989, 12, 937-941. [20b] J.-T. Huang, L.-C. Chen, L. Wang, M.-H. Kim, J. A. Warshaw, D. Armstrong, Q.-H. Zhu, T.-C. Chou, K. A. Watanabe, J. Matulic-Adamic, T.-L. Su, J. J. Fox, B. Polsky, P. A. Baron, J. W. M. Gold, W. D. Hardy, E. Zuckerman, J. Med. Chem. 1991, 34, 1640-1646.

[21] [21a] H.M. Kissman, M.J. Weis, J. Am. Chem. Soc. 1958, 80, 2575-2583. ${ }^{[21 b]}$ L. L. Terent'ev, N. A. Terent'eva, V. A. Rasskazov, L. A. Aleksandrova, L. S. Viktorova, A. A. Kraevskii, Biokhimiya (Moscow) 1985, 50, 1024-1029.

${ }^{[22] ~[22 a] ~ P . ~ H e r d e w i j n, ~ A . ~ V a n ~ A e r s c h o t, ~ L . ~ K e r r e m a n s, ~ N u c l e o s i d e s ~}$ Nucleotides 1989, 8, 65-96. [22b] J. Plavec, L. H. Koole, A. Sandström, J. Chattopadhaya, Tetrahedron 1991, 47, 7363-7376. ${ }^{[22 c]}$ J. J. Barchi Jr., L.-S. Jeong, M. A. Siddiqui, V. E. Marquez, J. Biochem. Biophys. Methods 1997, 34, 11-29.

[23] [23a] C. Altona, M. Sundaralingam, J. Am. Chem. Soc. 1972, 94, 8205-8212. [23b] C. Altona, M. Sundaralingam, J. Am. Chem. Soc. 1973, 95, 2333-2344.

${ }^{[24]}$ W. Saenger, Principles of Nucleic Acid Structure, Springer-Verlag, New York, 1984.

[25] J. Plavec, W. Tong, J. Chattopadhyaya, J. Am. Chem. Soc. 1993, 115, 9734-9746.

[26] [26a] J. van Wijk, C. A. G. Haasnoot, F. A. A. M. de Leeuw, B. D. Huckriede, A. Westra Hoezema, C. Altona, PSEUROT 6.2 1993, Leiden Institute of Chemistry, Leiden University. ${ }^{[26 \mathrm{~b}]} \mathrm{C}$. Altona, Recl. Trav. Chem. Pays-Bas 1982, 101, 413-433. [26c] F. A. A. M. de Leeuw, C. Altona, J. Comput. Chem. 1983, 4, 428-437.

[27] C. Thidaudeau, J. Plavec, N. Garg, A. Papchikhin, J. Chattopadhyaya, J. Am. Chem. Soc. 1994, 116, 4038-4043.

${ }^{[28]}$ H. P. M. De Leeuw, C. A. G. Haasnoot, C. Altona, Isr. J. Chem. 1980, 20, 108-126.

${ }^{[29]}$ V. E. Marquez, M. A. Siddiqui, A. Ezzitouni, P. Russ, J. Wang, R. W. Wagner, M. D. Matteucci, J. Med. Chem. 1996, 39, $3739-3747$

${ }^{[30]}$ P. Van Roey, W. E. Taylor, C. K. Wu, R. F. Schinazi, Ann. N. Y. Acad. Sci. 1990, 616, 29-40.

${ }^{[31]}$ C. Blondin, L. Serina, L. Wiesmuller, A.-M. Gilles, O. Barzu, Anal. Biochem. 1994, 220, 219-221.

${ }^{[32]}$ D. J. States, R. A. Haberkorn, D. J. Ruben, J. Magn. Res. 1982, 48, 286-292.

${ }^{[33]}$ L. A. Donders, F. A. A. M. De Leeuw, C. Altona, Magn. Res. Chem. 1989, 27, 556-563.

Received March 14, 2003 